\title{
II. Dünya Savaşı Yıllarında Türkiye’de Bir Dergi: Yurt ve Dünya
}

\section{Hasan DİNÇER*}

\section{ÖZET}

II. Dünya Savaşı, Türkiye’yi dış politikada olduğu kadar iç politika konularında da derinden etkilemiştir. 1939-1945 arası dönemde Türkiye çok taraflı anlaşmalar ile savaşın dışımda kalmaya çalışırken, uygulamaya koyduğu askeri tedbirler sebebiyle geniş kitlelerin hayatını zorlaştıran iktisadi sorunlarla karşı karşıya kalmıştır.

Savaş karşısında belirlenen denge politikası ve ă̆ır ekonomik sorunlar, hükümetlerin basın karşısında izledĭ̆i tutumu da belirlemiştir. Dergi yayıncılığında

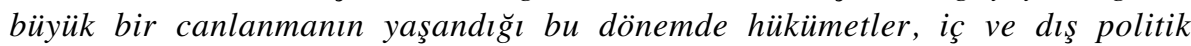
gelişmelere göre sıklıkla gazete ve dergileri kapatma yoluna gitmiştir.

Bu incelemenin konusu olan Yurt ve Dünya dergisi de bu dönemde yayınlanmaya başlamıştır. İlk sayısı Ocak 1941, son sayısı Mart 1944'te yayınlanan ve Nisan 1944'te Bakanlar Kurulu karart ile kapatılan derginin çekirdek yazar kadrosu Adnan Cemgil, Pertev Naili Boratav, Hüseyin Avni Şanda, Niyazi Berkes ve Mediha Berkes'ten oluşmuştur.

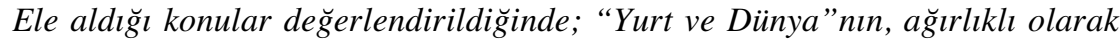
ırkçılık-Turancılık ve faşizm karşıtlı̆̆ı, kapitalizm eleştirisi, makineleşme yoluyla köy nüfusunun azaltılarak sanayiye aktarılması, Kemalizm'in kazanımlarına sahip çıkılması, bilimin ba ğımsızlığının savunulması gibi düşüncelere yer veren bir dergi olduğu görülmektedir.

Türkiye II. Dünya Savaşı'nda tarafsı kalmakla birlikte Almanya ile daha yakın siyasi ilişkiler geliştirmişti. Şubat 1943'te Almanların Stalingrad'daki yenilgisi ile hükümetin dış politikası de ğişirken dergilere karşı tutumu da sertleşmiş; ırkçıTurancı dergilerle birlikte sol dergiler bu arada Yurt ve Dünya dergisi de kapatılmıştır.

Anahtar Kelimeler: Köy, köylülük, tarımda makineleşme, sanayileşme, şehirleşme, faşizm ve ırkçılık-Turancılık karşıtlı̆̆ı, kapitalizm eleştirisi, Hümanizm,

* Ankara Üniversitesi Türk İnkılap Tarihi Enstitüsü Öğretim Görevlisi 
Adnan Cemgil, Pertev Naili Boratav, Hüseyin Avni Şanda, Niyazi Berkes ve Mediha Berkes.

\begin{abstract}
World War II influenced Turkey not only in terms of foreign policies but also of domestic policies. During the era between 1939 - 1945, while Turkey was striving for keeping out of the war by means of bilateral agreements, she also faced various economic problems making life difficult for the vast majority due to military measures it implemented.
\end{abstract}

The policies of balance assumed before the war and heavy economic problems also determined the attitude that the government assumed towards the press. In this era when a great boost was experienced in magazine press, the governments frequently resorted to measure of shutting down daily papers and magazines based on the domestic and foreign political development.

Yurt and Dünya (Homeland and World) magazine which is subject matter of this paper started to be published in this era. Core writer cadre of the magazine which published its first issue in January 1941 and last issue in April 1944, consists of Adnan Cemgil, Pertev Naili Boratav, Hüseyin Avni Şanda, Niyazi Berkes and Mediha Berkes.

When the subjects it covered are examined, it's seen that it was a magazine which covers such notions as anti-racism, anti-Turanism and anti-fascism in Turkey and in the world, criticism of capitalism, reduction of the rural population and transferring them to the industry, embracing gainings of Kemalism, defending independence of the science.

While Turkey was impartial during World War II, she developed closer political relationships with Germany. While with the defeat of Germans in Stalingrad in 1943, the foreign policies of the government changed, and not only racist-turanist magazines but also leftist magazines including Yurt ve Dünya magazine were shut down.

Keywords: Village, ruralism, mechanization in agriculture, industrialization, urbanization, anti-fascism and anti-racism-turanism, criticism of capitalism, Humanism, Adnan Cemgil, Pertev Naili Boratav, Hüseyin Avni Şanda, Niyazi Berkes and Mediha Berkes.

\title{
GİRIŞ
}

1939-1945 arası dönemde dünya, kapitalizmin, 1929 Bunalımı'ndan hatta I. Dünya Savaşı'ndan beri birikmekte olan bunalımlarına savaş yoluyla 


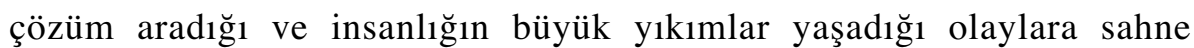
olmuştur.

II. Dünya Savaşı'nın Türkiye'ye yansıması, ekonomiden, siyasete ve sosyal hayata yoğun olumsuzluklar şeklinde olmuştur. Alınan askeri tedbirlerin ve dünya ticaretinin daralması üretimin düşüşüne, enflasyona, yolsuzluğa, nihayetinde çoğunluğu oluşturan kitlelerin yaşam standardının düşüşüne sebep olurken; aynı koşullar, tüccar ve toprak sahiplerinin, ticaret burjuvazisine dönüşmelerini ve yakın gelecekte Türkiye'nin siyasi hayatını derinden etkileyecek kadar güçlenmelerini hazırlamıştır.

Türkiye'nin II. Dünya Savaşı'ndan etkilenmesi elbette sadece ekonomik konular ile sınırlı değildi. Almanya ve İtalya'da yeşeren faşizm ve Nasyonal sosyalizm de etkilerini Türkiye'ye kadar ulaştırabilen unsurlardı. Bu etki devleti yönetenlerden aydınlara kadar geniş bir alan için söz konusu idi. Devlet yöneticilerinin faşizm ve nazizme ve bunların yüksek olasılıklı zaferine bakışı, Türkiye'nin dış politikasına siyasi antlaşmalar, ticari ilişkiler olarak yansırken, dergiler ve gazetelere karşı izlenen hükümet politikaları büyük çapta dış politik gelişmelere bağlı olarak şekillenmiştir.

II. Dünya Savaşı yıllarında, Türkiye'de gazete ve dergi yayıncılığı ve bu yolla ortaya konan düşünce panoraması, iktisadi alandaki yokluk ve kıtlıklar ile ters orantılı bir zenginlik ve çeşitlilik ${ }^{1}$ gösterir. Gazeteler daha çok dış politika, ekonomik sıkıntılar ve bunların halka yansıması konularına yer verirken, dergilerde daha çok faşizme karşıt veya taraftar olmaya bağlı olarak şekillenen düşüncelere yer verilmiştir.

Bu yazıya konu olan Yurt ve Dünya dergisi bu koşullarda yayınlanmaya başlamış ve yine bu dönem içinde kapatılmıştır. Yazımızda, zengin bir içeriğe sahip olan dergi, ele aldığı konular açısından genel anlamda tanıtılırken 1940'lar Türkiye'sinin sosyal ve ekonomik sorunlarına, ırkçılık ve faşizm olgularına nasıl yaklaştığı konusunda daha geniş olarak ele alınacak ve değerlendirilecektir.

Yurt ve Dünya Dergisi: Yayın Hayatına Başlaması ve Kendisini Takdimi

Yurt ve Dünya dergisi yayın hayatına Sonkanun (Ocak) 1941'de Ankara'da başlamıştır. Derginin neşriyat müdürü, yayınlandığı kırk iki sayı boyunca Adnan Cemgil, imtiyaz sahibi ilk yirmi bir sayısında Behice Sadık Boran, yirmi ikinci sayısından itibaren Pertev Naili Boratav'dır. 15-16, 22-23, 26-27. sayıları bir arada basıldığ 1 için dergi toplam otuz dokuz

1 “1940 yılları da "Dergi” yılları oldu”. Yalçın Küçük, "Cumhuriyet Döneminde Aydınlar ve Dergileri”, Cumhuriyet Dönemi Türkiye Ansiklopedisi, C.I, İletişim Yayınları, İstanbul, 1983, s. 141 
nüshadır. ${ }^{2}$ Recep Ulusoğlu Matbaası'nda aylık olarak basılan dergi 38. sayısından (15 Sonkanun 1944) itibaren on beş günde bir yayınlanmaya başlamıştır.

Derginin, hikaye yazarlarından şairlere, sosyologlardan mühendislere uzanan zengin bir yazar kadrosu olmakla beraber, hemen her sayısında yazı yazan çekirdek kadrosu Adnan Cemgil, Pertev Naili Boratav ${ }^{3}$, Hüseyin Avni Şanda, Niyazi Berkes ve Mediha Berkes'ten oluşmaktadır.

Ocak 1941'de yayın hayatına başlayan Yurt ve Dünya dergisi ilk sayısında yayın anlayışını ve hedeflerini şöyle ifade etmiştir:

"Bu sahifelerde başarmak istediğimiz iş bakımından "Yurt ve Dünya" adını coğrafi manada değil, sosyal manada alıyoruz. Maksadımız sadece yurt ve dünyada olup bitenleri okuyucularımıza bildirmek değildir. Daha ziyade yurt ile dünyanın münasebeti üzerinde durmak istiyoruz. Yurt ile dünya arasında cüzü ile kül arasındaki münasebet vardır. Bu münasebet karşılıklı tesirler ve bağlllıklardan mürekkeptir."

"Denilebilir ki, ilim ve sanat, mücerret şeyler olmayıp bütün varlıklarıyla bir devrin ve bir cemiyetin adamı olan insanların eserleri olduğuna göre bu devirlerin ve sosyal muhitlerin tesirini taşımayacak mıdır? Bu suale cevap olarak ilim ve sanatın cemiyetten cemiyete değiştiğini ortaya sürerek bunların külli hakikatlere erişmeye çalışan insan faaliyetleri olduklarını inkar edenler vardır. Bu kimseler ilim ve sanatta dar bir mahallilik taraftarıdırlar. Hiçbir insan faaliyeti yoktur ki içtimai muhitinin damgasını taşımasın; ilim ve sanat bu kaidenin dışında değildir. ${ }^{4}$

Türkiye'yi dünya ile bir bütün olarak gören ve ülke sorunlarını bu bütün içindeki etkileşim çerçevesinde ele alacağını belirten dergi, bilimi de hayatın realitelerine bağlamakta ve bilime, sosyal hayatı anlama ve değiştirme görevi yüklemektedir:

"İlmin meşgul olacağı esas meseleleri, ilmi metodun tatbik olunacağı başlıca realite sahalarını içtimai şartlar tayin eder. İçtimai şartların ilmi faaliyete verdiği bu istikametin ilim adamı fert olarak farkında olur veya olmayabilir; yani şuurlu olarak pratik meselelerin halli ile uğraşır veya "ilim,

${ }^{2}$ Abdurrahim Karadeniz, Düşünce ve Edebiyatımızda Yurt ve Dünya Dergisi, Kültür Bakanlığı Yayınları, Ankara, 2002, s.10

3 "Çoğunluğunu Amerika'da sosyoloji okumuş ve dönüşlerinde Dil ve Tarih Coğrafya Fakültesine doçent olarak atanmış genç bilim adamlarının oluşturduğu bir grup, "Yurt ve Dünya" adlı... bir dergi çıkarmaya başlamışlardı." Baskın Oran, "İç ve Dış Politika İlişkisi Açısından İkinci Dünya Savaşında Türkiye'de Siyasal Hayat ve Sağ -Sol Akımlar", A. ̈̈. SBF Dergisi, 23 (3), 1969, s. 262. Çekirdek kadronun dışındaki 67 yazar dergiye telif ve çeviri makaleler, öykü ve şiirlerle katkıda bulunmuşlardır. Meltem Ağduk Gevrek, "Yurt ve Dünya/1941-1944 1940'ların "solunun” Ankara Çevresi”, Toplum ve Bilim, S. 78, Güz, 1998, s. 256

4 "Yurt ve Dünya", Yurt ve Dünya, S.1, Sonkanun 1941, s. 1, 2 
ilim içindir" zihniyetiyle çalışır. Fakat sübjektif bakımdan fert, faaliyetini her ne türlü telakki ederse etsin, ilmi faaliyetin yer tutması için bir içtimai fonksiyonu bulunması lazım gelir.

“... Bugünün Türk cemiyeti en geniş ölçüde ve her sahada, "dünya” ile daimi münasebet halinde olduğuna göre, "yurda" ait her problemin, "dünya" meselelerinin çerçevesinde düşünülmesi lazımdır. İşte, çalışmalarımızın ve yazılarımızın hareket noktası bu anlayış olacaktır ${ }^{5}$.

Derginin yazar kadrosunun zenginliği derginin içeriğini de zenginleştirmiştir. Bundan dolayı derginin çeşitli konulardaki görüşlerini ortaya çıkarmak için yazılar konularına göre bir sınıflamaya tabi tutulmuştur.

\section{Ekonomi Yazıları}

\section{Osmanlı Ekonomisi}

Yurt ve Dünya dergisindeki ekonomi yazıları, Osmanlı Devleti'nin özellikle son yüz elli yılına dair tahliller ve II. Dünya Savaşı'nın Türkiye'de yarattığı ekonomik sıkıntılar, dönüşümler, uygulanan tedbirler olarak bölümlenmektedir.

Osmanlı Devleti'nin yıkılış süreci 19. yy ortalarından itibaren ve gelişmiş Batı ile ilişkileri çerçevesinde ele alınmıştır. Osmanlı devletinin yarı-sömürge olma süreci ve endüstrileşme politikalarının başarısızlı̆̆ı; devletin iktisadi bir bütünlükten yoksun oluşu, dış ticaretin emperyalizmin elinde oluşu, kapitülasyonlar ve feodal engelleri yıkarak kurucu bir sanayi politikası izleyecek güçlü devletin yokluğuna ${ }^{6}$ bağlanmıştır. Dışa açık ekonomi politikalarının Osmanlı ekonomisinin bankacılık, sigorta, tekstil gibi alanlarının yabancı egemenliğine girmesine sebebiyet verdiği vurgulanırken dönemin önde gelen kişilerinden Ahmet Mithat korumacı ekonomiyi, Sakızlı Ohannes Paşa ve Portakal Mikael serbest ekonomiyi savunan kişiler olarak eserlerinden ${ }^{7}$ alıntılarla öne çıkarılmıştır.

Osmanlı ekonomisinin bağımlı niteliğini değiştirmek amacıyla Abdülaziz ve Abdülhamit dönemi çabalarının istenen sonucu vermediği belirtilirken İttihat ve Terakki Partisi'nin iktidar yıllarında izlenen milli bir burjuvazi yaratma politikalarına ayrı bir önem atfedilmiştir: “...Ittihat ve Terakki, milli ${ }^{8}$ sirketler, milli bankalar yoluyla Türk-Müslüman büyük tüccar grupları oluşturma teşebbüsüne girişmiş̧tir."

\footnotetext{
5 "Yurt ve Dünya", Yurt ve Dünya, S.1, Sonkanun 1941, s. 2, 3, 5

${ }^{6}$ A. Münir Belen, "Osmanlı Imparatorluğu Sonlarında Endüstri Politikası", Yurt ve Dünya, S. 20, 29 İlkteşrin 1942, s. 277

7'Hüseyin Avni Şanda, "Yarı Koloni Münevverleri”, Yurt ve Dünya; S.17, Mayıs 1942, s. 137,138 .

${ }^{8}$ Hüseyin Avni Şanda, "Bizde İlk Anonim Şirketler”, Yurt ve Dünya, S. 36, İlkkanun 1943, s. 483
} 
İttihat ve Terakki Partisi'nin, kapitülasyonları kaldırması (1914), Teşvik-i Sanayi Politikası (1913), Sanayi Sayımı (1914) gibi uygulamalarının olumlu sonuçları olarak, yerli girişimci tarafından 1914-1918 yılları arasında İstanbul ve Anadolu'da 50'ye yakın anonim şirketin kurulması gösterilmiştir.

Avrupa kapitalizminin Osmanlı topraklarındaki ekonomik egemenliğinin tüketilen mamul maddeler için de söz konusu olduğu belirtilerek bu alandaki gelişmelere de değinilir: " Avrupa menşeli malları satmak için Beyoğlu, Galata ve Bahçekapı'da büyük mă̆azalar açılmış, zarara uğrayan Kapalıçarşı ve Mahmutpaşa esnafı bu oluşuma tepki $i^{9}$ göstermiştir.” Ordu ve Donanma Pazarı ile Malul Gaziler Pazarı'nın kuruluşu bu tepkilerin eseridir. Ancak bütün bu gelişmelerin yerli üretim düzeyine ulaşmaktan uzak olduğu şu cümle ile vurgulanmıştır: "Yüzde yüz yerli eşyası satan mă̆azalar bizde ilk defa olarak Sümerbank tarafindan "Yerli Mallar Pazarı" ismi altında kurulan mağazalardır." 10

Osmanlı Devleti'nin Batı ile olan iktisadi ilişkileri ve bunun sonuçları üzerine yazılan genel çerçeveli yazıların yanında 19. yüzyılda İstanbul'un iaşe sorunları, İzmir'e Batı sermayesinin nüfuz etmesi ile İzmir'deki şirketleşme, tarımsal üretimin pazara dönük hale gelmesi ve tarımsal ürün çeşitliliğinin artması, Türk Ticaret Bankası'nın kuruluş süreci ${ }^{11}$ gibi dar çerçeveli yazılar da yayınlanmıştır.

İster dar ister geniş çerçeveli yazılar olsun Cumhuriyet öncesi iktisadi gelişmelere; Avrupa merkezli kapitalizmin geleneksel üretim biçimlerini yıkıcılığ 1 , bağımlı hale getirişi çerçevesinde bakılmıştır. Osmanlı devleti, kapitalizmin emperyalist niteliği sebebiyle yerli üretici güçleri yıkıma uğramış, modern, gelişmiş ve bağımsız bir ekonomi kuramamış ülke olarak tasvir edilmiştir. İttihat ve Terakki Partisi'nin iktidar yıllarında, Türklerin burjuvalaşma eğiliminin güçlendiği ama bunun daha çok yabancı veya gayrimüslim tüccarın yerini alma düzeyinde kaldığ 1 görüşü savunularak bir anlamda, yerli üretimi de gerçekleştirebilmiş bağımsız bir ekonominin kurulmasında Cumhuriyet dönemi, milat olarak kabul edilmiştir.

II. İkinci Dünya Savaşı'nın Türkiye'de Yarattı̆̆ı Ekonomik Sorunlar ve Değişim

II. Dünya Savaşı yıllarının, Türkiye'nin savaşa dönük tedbirleri hayata geçirmesi ve buna bağlı olarak tarımsal üretimde düşüş̧, gıda maddeleri

\footnotetext{
${ }^{9}$ Hüseyin Avni Şanda, "Osmanlı İmparatorluğunda Yabancı Ticaret Müesseseleri”, Yurt ve Dünya; S.35, Sonteşrin 1943, s. 442

${ }^{10}$ Hüseyin Avni Şanda, "Osmanlı İmparatorluğunda Yabancı Ticaret Müesseseleri", Yurt ve Dünya; S.35, Sonteşrin 1943, s.443

${ }^{11}$ Hüseyin Avni Şanda, "Meşrutiyette Milli Ekonomi Cereyanları", Yurt ve Dünya, S.15-16, Mart-Nisan 1942, s.77,78
} 
darlığı, enflasyon, karaborsa, istifçilik, tüccar sınıfının bu koşulları geniş halk kesimleri aleyhine istismar etmesi gibi gelişmelerin yaşandığı bir dönem olması, Yurt ve Dünya dergisinin bu konulara geniş yer ayırmasını sağlamıştır.

Yukarıda değinilen konuları ele alan yazılarda savaş koşulları ile eşya fiyatlarının muazzam artışına paralel olarak tüccar sayısındaki ve sermaye birikimindeki artışa dikkat çekilirken tüccar artışının ürünlerin daha çok el değiştirmesine sebep olduğu, dolayısıyla fiyatların daha da arttığ 1 belirtilmektedir.

Savaşın, uluslararası ticareti daraltmasının sonucu olarak Türk tüccar sınıfının daha çok iç ticare ${ }^{12}$ yoluyla zenginleştiği saptaması yapılırken bu olgunun hayat pahalılığını arttıran en önemli nedenlerden olduğu belirtilmektedir. Savaş koşullarının kentlerdeki tüccar sınıfı için yarattı̆̆ 1 fırsatlar ve bunların insafsızca değerlendirildiği yorumlarının yanında bu koşulların köylülük üzerindeki etkilerine de yer verilmiştir.

Anadolu'nun tarımsal üretim, özellikle buğday üretimi ile öne çıkmış şehirlerinde yapılan tetkiklere dayanılarak Polatl ${ }^{13}$, Afyon, Çubuk, İzmir ve Konya'da yüksek fiyata buğday satıldığg, bunun köylülüğün iktisadi hayatında bir sıçrama ve tüketim alışkanlıklarında önemli değişiklikler yarattığ1, buralarda şeker, kahve, ipekliler, gramofon, plak gibi ürünlerin tüketilmeye başlandığı belirtilirken kasaba tüccarının bu durumdan -ki istediği fiyattan buğday alamamaktan kaynaklanan- rahatsızlığını daha çok köylüyle alay ederek yansıttığı belirtilmiştir. Zenginleşen köylülere ilişkin yapılan değerlendirmeler, sadece değişen tüketim alışkanlıkları ile sınırlı kalmamış; köyde yaşamayı sürdürenlerin birikimleriyle toprak satın alırken taşra kökenli tüccarların İstanbul'a, İzmir'e akın ettiği, şirket kurduğu ya da şirketlere ortak olduğu belirtilmiştir.

Köylülerin yaşam standardında görülen yükselmeye karşı gazetelerde ortaya konan tepkiler yersiz bulunmuş, öncelikle zenginleşen köylüler olgusunun genel bir durum olmadığı, ayrıca ziraat aletleri başta olmak üzere köylülerin tükettiği ürünlere talebin arttığı vurgulanarak önce köye akan sermayenin tekrar şehre akacağı vurgulanmıştır. Aydın ve tüccarların, köylünün köyü terk ederek toprakla uğraşmama ihtimalini öne sürerek sert tedbirler alınması yolundaki basında çıkan önerileri yanlış bir tutum olarak

\footnotetext{
${ }^{12}$ Hüseyin Avni Şanda, "D1ş Ticaret ve Harp”, Yurt ve Dünya, S. 38, 15 Sonkanun 1944, s. 62

${ }^{13}$ Şanda, zenginleşen köylüler için “...içtimai tip tahavvülü geçiren köylüler...”" ifadesini kullanmaktadır. Hüseyin Avni Şanda, "Köylüyle Kim Alay Ediyor”, Yurt ve Dünya, "S. 22-23, İlkkanun 1942, s. 371,372.
} 
eleştirilmiş, yaşananlar, doğal ve müdahale edilmemesi gereken gelişmeler olarak $^{14}$ değerlendirilmişsir.

Birkaç şehir ve büyük arazilere sahip sınırlı sayıdaki köylü için söz konusu olan sermaye birikimi ve hayat seviyesinin yükselmesi olgusunun yanında, köylülüğe ilişkin olumsuzluklar derginin sayfalarında daha geniş yer tutmuştur.

Ülkede yer yer takas ekonomisinin yaşamakta olduğu, Tokat, Zile, Kayseri ve Turhal'da iklim koşullarının da elverişsizliği ile kıtlıkların ${ }^{15}$ baş gösterdiği bilgisine yer verilmiştir. Ekinlerin kötü olmasının hayvancılığı da kötü etkilediği, bütün bunlara, tüccarın, ürün çıkmadan köylüyü borçlandırmak suretiyle ürünü önceden satın almasının eklendiği belirtilmiştir. Gazetelerin, geçim ve iaşe işlerinde daha çok şehirlerin yaşadığı sorunlara dikkati çektiği, adeta köylüleri bu sorunlardan uzak, hatta sıkıntıların kaynağı gibi gösterdiği ifade edilerek köyler üzerine yazılar yazılmamasından şikayet edilmiştir. ${ }^{16}$ Bezirganların, elinde buğday ve paranın kalmadığı dönemde köylüye mal sattığı, bunun köylü aleyhine bir alışveriş olduğu üzerinde durularak köylünün zorunlu ihtiyaçları ile hububat satışı arasında bir denge kurulamadığı vurgulanmıştır. Bundan dolayı küçük ve orta halli rençperlerin zengin ağa kesimi karşısında topraklarını kaybetmek tehlikesi yaşadığı belirtilmiştir.

Olumsuzluklar arasında, hükümetin uygulamaya koyduğu tarım ürünlerinin \% 25'ini devlete satma zorunluluğu ve askere alma sebebiyle ekilemeyen tarım alanları da sayılmaktadır. Bu tespit Yurt ve Dünya dergisinde pek az rastlanan CHP eleştirisi olarak da değerlendirilebilir.

Dergide II. Dünya Savaşı yıllarında yaşanan ekonomik sıkıntılar kadar yer verilmese de hükümet tedbirlerine de değinilmiştir. Bu çerçevede 1942 yılında CHP Hükümeti'nin, İaşe Müsteşarlığı ve Tevzi Ofisi'ni kuracağını duyurması da dergide ele alınmıştır. Trabzon'a yapılan tetkik gezileri ile Akçaabat ilçesinde, 5 tüccarın 35 bakkal aracılığıyla 88 köye mal dağıttı̆̆ 1 belirtilmiş bakkalların yüksek faizle köylüleri borçlandırdı yaşanan mal darlığı sebebiyle tüccarın mallarını fahiş fiyatla sattığı belirtilerek bir anlamda hükümete mesaj olabilecek şu temenni iletilmiştir:

${ }^{14}$ Hüseyin Avni Şanda, "Hangi Köylü Zenginleşiyor", Yurt ve Dünya, S. 20, 29 Ekim (İlkteşrin) 1942, s.295,296

${ }^{5}$ Mediha Berkes, ekonomik sıkıntılar ve yoklukların köylülerin misafir ağırlama ve düğünlerdeki ikramlarında azalmaya sebep olduğunu belirtmektedir. Mediha Berkes, "Köyde Yaşayıs", Yurt ve Dünya, S. 30, Haziran 1943, s. 192-195.

${ }_{16}^{16}$ Halil Aytekin, "Köylerin Bugünkü İaşe Durumu", Yurt ve Dünya, S. 36, İlkkanun 1943 , s. 486-490 
"Netice olarak diyebiliriz ki bozulan tevzi ${ }^{17}$ cihazı yerine bir yenisini kurmak lazımdır."

Cumhuriyet tarihinin en tartışmalı konularından ve günümüze kadar araştırmacılar için popülaritesini yitirmemiş olan Milli Korunma Kanunu ve Varlık Vergisi de dergide ele alınan konulardandır. Savaş koşulları ile yaşanan mal darlığını toplumsal sarsıntı yaratacak düzeyde aşırı kar elde etmek üzere kullanan tüccar sınıfına karşı hükümetin tepkisi olarak nitelenen Varlık Vergisi, "işte bu zamanlarda bu gibilerin ahlaki ve insani olmayan hırsını, milli korunma ve ona benzer kanunların ceza müeyyideleriyle önlemek gerektiği kadar..." ${ }^{18}$ şeklindeki ifadeyle hükümetin, karaborsa, fiyat artışı ve istifçilikle mücadele etmek için yaptığ 1 düzenleme, doğal ve gerekli bir uygulama olarak yorumlanmıştır.

Varlık Vergisi'nin gelir elde etmek için değil enflasyonu düşürmek, malların piyasaya çıkmasını sağlayarak fiyatları istikrara kavuşturmak için uygulandığı belirtilerek bu vergi ile haksız kazanç sahiplerinin hedeflendiği belirtilmiştir. Hükümetin Varlık Vergisi konusunda temyiz yolunu kapatması da tedbirin aciliyetine bağlanarak doğru bir tutum olarak değerlendirilmiştir.

II. Dünya Savaşı'nın Türk toplumuna yansıyan sonuçlarına dair yazılan yazılar genel olarak değerlendirildiğinde savaş koşullarında zenginleşen sınırlı sayıdaki büyük çiftçiye, kentli tüccara oranla daha 1lımlı yaklaşıldığ 1 görülmektedir. Köylülüğün genelindeki hayatın zorlaşması, tüccarın oynadı̆̆ı menfi rol en çok dikkat çekilen ve işlenen konular olmuştur. Hükümetlerin 1940'lı yıllardaki uygulamaları genelde onaylanırken eleştiri sayılabilecek kısımlarda yumuşak bir dil kullanılmaya özen gösterilmiştir.

\section{Kapitalizm Eleștirileri}

Yurt ve Dünya dergisinde, Türkiye'deki ekonomik gelişmeleri ele alan yazıların yanında, Batıda gelişen kapitalizmin tahlilini ve eleştirisini içeren yazılara da yer verilmiştir. Bu yazılar kapitalizmin tarihsel gelişim süreci, burjuva sınıfının mücadelesi, burjuvazinin temel nitelikleri, emperyalizm gibi konuları içermektedir.

Modern Ekonominin tarihsel gelişiminin açıklanmasına kapitalizmle ilgili bazı terimlerin açıklanması ile başlanmış; "Piyasa, $<<$ para $^{19}$ istediği her şeyi istediği yerde ve istediği zamanda satın alabilir $>>$ prensibi ile hülasa edilebilir." şeklinde tanımlanmıştır. Avrupa'da derebeylik döneminde kapalı bir ekonomik ve toplumsal yapının var olduğu, yukarıda tanımlamaya uyan

${ }^{17}$ Hüseyin Avni Şanda, "Köy Bakkalları ve Kahvecileri”, Yurt ve Dünya S.13, İkinci Kanun 1942, s. 11

${ }^{18}$ A. Münir Belen, "Varlık Vergisi”, Yurt ve Dünya, S.22-23, İlkkanun 1942, s.374. s. 206

${ }^{19}$ Niyazi Berkes, "Modern Ekonominin Doğuşu”, Yurt ve Dünya, S. 30, Haziran 1943, 
bir piyasanın var olmadığg belirtilerek 15. yüzyıldaki üretim araçları, nakil araçları, yollar ve gemicilikteki ilerlemeler ile pazarın büyümeye başladığı belirtilmiştir.

Pazarın büyümesi tüccarların büyümesi anlamına geldiğinden tüccarlar ticaret önündeki derebeylik kural ve kısıtlamalarının kaldırılması mücadelesine girişmişlerdir. Bu mücadelede önce kilisenin ticarete köstek olan dini engelleri yıkılmış ardından feodal beylere karşı krallarla işbirliği yapılmıştır. Nihayetinde burjuvazi, kralları da yıkarak devlet mekanizmasını ele geçirme mücadelesini başlatmıştır. Bu tarihsel mücadeleler sonucunda, ekonomi ve yönetimde yaşanan değişikliklerin, özel mülkiyetin kutsallığını esas alan bir siyaset felsefesinin ortaya çıkışı ile tamamlandığı belirtilmiştir. Üretim tekniğinde yaşanan devrim (makineleşme) ile işçi sınıfının doğduğu belirtilerek ticaret burjuvazisinin de sanayi burjuvazisine dönüştüğü kaydedilmiştir. Bu arada İngiltere ve Fransa'da yaşanan bu değişimlerin özellikle Avrupa dışı toplumlara yansıma ve etkisinin, yeni sanayinin dünyanın diğer alanlarına açılmasıyla, daha geri sanayiye sahip ülkelerin üretimini çökertmek şeklinde olduğu belirtilmiştir.

Kapitalizmin doğuşuna ilişkin genel açıklamaların yanında burjuvazinin, egemen olduğu ülkelerde toplumsal sınıfların konumunu nasıl değiştirdiğine, kendi çıkarları doğrultusunda sosyal ve ekonomik yapıyı nasıl şekillendirdiğine de değinilmiştir. Çoğalan iş sahalarının işbölümünü arttırdığı, dolayısıyla işçi sınıfını yarattı̆̆ kolları arasında bir ahenk sağlama zorunluluğunu doğurduğu diğer taraftan da insanlar arası ilişkileri emtialar arası ilişkiler kılığına dönüştürdüğü vurgulanmıştır.

Derebeyliğin yıkılışı ile toprak köleliğinin sona ermesinin ve toprağın daha verimli kullanılmaya başlanmasının ekonomik açıdan bir ilerleme ${ }^{20}$ olduğu ancak feodal dönemin köleliği, serfliği ve angaryasının yerini yeni bir zorunlu işçiliğin aldığı bunun da "burjuvazinin emrinde çalışmak" olduğu belirtilmiştir. Bu mutlak bir zorunluluk haliydi zira, derebeylikten kurtulanları işçi haline getirmek için köylüler, tarlaları zorla alınmak suretiyle ücret karşılığı emeğini kiralamak zorunda bırakılmıştı. Bir yandan elle üretenler makineleşme ile pozisyonlarını kaybederek işçi olmakta diğer yandan da insan emeği emtia haline gelmekteydi. Bütün bu süreçlerin, toplumu, emeğini kiralayanlar ve üretim araçlarına sahip olanlar olmak üzere iki kesime ayırdığı vurgulanırken ortaya çıkan tablonun, J.J. Rousseau'nun umduğu "küçük, müstakil ve müsavi müstahsillerden mürekkep olan bir cemiyet..." olmaktan çok uzak olduğu belirtilmiştir. Zira feodal bağlılıklar yıkılmış olsa da, medeni hürriyetin yerine çok daha tesirli ve şümullü bir

\footnotetext{
1943

${ }^{20}$ Niyazi Berkes, "Modern Ekonominin Temelleri”, Yurt ve Dünya, S.31, Temmuz
} 
iktisadi tabiiyet şekli meydana gelmiştir. Bu yanında burjuvazinin bütün bu süreçler boyunca sermaye birikimi yolunda başka ülkeleri soymak ve kilise, derebeyi topraklarını müsadere etmek için çalıştı̆̆ 1 bilgisine de yer verilmiştir.

Kapitalizmin doğuşuna ilişkin yazıların ardından kapitalizmin olumsuzluklarının ve iç çelişkilerinin ele alındı $\breve{g}_{1}$ görülmektedir. Kapitalizmin, doğası gereği tekelci kapitalizm aşamasına ulaştığı, tekelleşmenin, kapitalizmin esaslarından olan serbest piyasanın can düşmanı olduğu vurgulanarak feodalitenin tekelciliğini yıkarak yerine kendi tekelciğini kurduğu ${ }^{21}$ belirtilerek bir anlamda burjuvazinin ilerici niteliğini kaybederek feodalitenin konumuna oturduğu savunulmuştur. Burjuvazinin iktidarı ele geçirdikten sonra üretimi ve karı arttıracak bilim kollarını ve bu alandaki gelişmeleri desteklemesine karşın toplumların gelişimine dair fikirleri, felsefeleri geriletmeye çalıştığı ifade edilerek örtük bir biçimde sosyalizme dair fikirlerin ve sosyalist ${ }^{22}$ mücadelelerin burjuvazinin düşmanca tavrı ile karşılaştığı vurgulanmıştır: "Halk kitlelerinin gözleri ilerilere değil gerilere çevrilmek isteniyor."

1940'lı yılların II. Dünya Savaşı yılları olması ve savaşın çıkışında faşist ideoloji ve politikaların ağırlıklı bir rol oynaması sebebiyle, kapitalizme dair eleştirel yazılar, kapitalizm ile faşizm arasındaki ilişkiyi ele alan yazılar ile bütünlenmiştir. Faşizme dair yapılan çözümlemelerde faşizm, "kapitalist ekonomi sisteminin bir zıddı, onu kaldıran bir inkılap değil, onun tabii ve mantıki bir neticesi ve devamıdır." ${ }^{, 23}$ denilmiş, bu görüş tarihsel gelişmeler ışığında açıklanmıştır. Buna göre faşizm, Avrupa'daki ekonomik gelişmelerin bir sonucudur. Kapitalizm yayılmacıdır ve hammadde ve pazar sahaları için 1914-1918 arası dönemde büyük bir savaş yaşanmıştır.

I. Dünya Savaşı sonrasında işçilerin sermaye sınıfına karşı mücadeleleri de faşizmi yaratan diğer olgulardandır. 1918 sonrasının memnuniyetsizlik ortamı sanayi ve tarım iş̧̧ilerinin burjuvazi karşısındaki mücadelesini s.299

${ }^{21}$ Niyazi Berkes, "Modern Ekonominin Tezatları”, Yurt ve Dünya, S. 32, Ağustos 1943,

${ }^{22}$ Ziya Oykut, "İlmin Sosyal Şartları", Yurt ve Dünya, S. 36, İlkkanun 1943, s. 482. Yurt ve Dünya dergisi genelde Marksist olarak nitelenmiştir. “... Yurt ve Dünya Marksist ve militan idi." Hilmi Ziya Ülken, Türkiye'de Çağdaş Düșünce Tarihi, 3. Baskı, Ülken Yayınları, İstanbul, 1992, s. 387. “... Yurt ve Dünya dergisi Marksizmi savunarak ...” Selahattin Hilav, "Düșünce Tarihi (1908-1980)", Türkiye Tarihi 4 Çăgdaş Türkiye 1908-1980, Cem Yayınevi, İstanbul, 1992, s. 385. Derginin yazarlarından Mediha Berkes'in, yıllar sonra, Yurt ve Dünya'nın Marksist olduğunu ifade ettiği nakledilmektedir. "M. Berkes: Yurt ve Dünya Marksist ve sol bir dergiydi. Fakat komünist değildik. Gerçi Marksist olduğumuzu da beyan edemezdik. Çünkü çok fazla baskı vardı. Sosyalizme, sola, ileriye açık, Atatürkçü idik." Meltem Ağduk Gevrek, "Yurt ve Dünya/1941-1944 1940'ların "solunun” Ankara Çevresi”, Toplum ve Bilim, S. 78, Güz, 1998, s. 263.

${ }^{23}$ Niyazi Berkes, "Modern Ekonominin Tezatlarından Faşizm", Yurt ve Dünya, S. 33, Eylül 1943, s. 325 
hazırlamıştır. Bu sınıfların başarılı mücadelesi karşısında burjuvazi, bu süreci ne burjuva ne işçi olan muhafazakar esnaf, küçük tüccar, memur, zanaatkar ve aydınları yanına çekerek durdurmaya çalışmıştır. Burjuvazi için tehlike olan parlamenter özgürlükçü rejimi bertaraf edecek nizam faşizm olmaktaydı. Bu sürece en çok uyan ülke İtalya'dır. İtalya'da halkın memnuniyetsizliği ve özleyişleri bir kuvvet haline getirilerek hem işçilere karşı kullanılıp tehlike savuşturulmuş hem de kapitalist ekonomideki topyekun inhisar sosyal alana da yayılarak sanayileşme ve temerküz de sürdürülmüş̧ür. Faşizm, tekelleşmeyi devlet eliyle uygularken parlak felsefelere bağlanmak istenen korporasyon sitemi ile ve de bu sitemin devlete bağlı olması sebebiyle işçilerin, gücünü hissettirmelerini de engellemiştir. Bu sebeple "... faşizm, kapitalizmin inhisarcılık safhasının tam gerçekleştiği şartları hazırlayan bir rejimdir."24

Faşizmin gelişim koşullarına ilişkin tahlillerin yanında çıkış yolunun ne olduğu konusunda da çok net ve belki de derginin ideolojik doğrultusunu daha kolay anlamaya yarayacak görüşlere yer verilmiştir. Kapitalizm ve onun doğal sonuçları olan emperyalizm ve faşizme son verebilmek, istenmeyen sonuçları doğuran kapitalizmin ortadan kaldırılabilmesine bağlanmıştır: " Emperyalizm kapitalizmin eseridir. Şu halde, onun ortadan kalkması, milletlerin sulha, refaha, milli istiklal ve terakkiye kavuşması için emperyalist mücadelelerin yok edilmesi lazımsa bu ancak onu zaruri olarak meydana getiren ekonomik sistemin kaldırılması ile kabildir." ${ }^{25}$

\section{Köy ve Köylülï̈̆е Dair Yazılar}

Türkiye, 1940'lı yıllarda nüfusunun \% 80’i köylerde yaşayan, sanayileşme yolunda önemli adımlar atmasına rağmen ekonomisi ağırlıklı olarak tarıma dayalı bir ülkedir. Bu olgu ülke gerçeklerini araştırmak için yola çıkan ve yazar kadrosunda sosyologların önemli yer tuttuğu Yurt ve Dünya dergisinde en çok yazı yazılan alanın köy ve köylülük olmasını hazırlamıştır.

Köye dair ilk yazılar, daha çok köy sosyolojisi çalışmalarında alışılagelmiş geleneksel bakış açılarının eleştirisi niteliğindedir. Köy tetkiklerinde elde edilen bulguların toplumsal yaşamın bütünlüğü içinde ele alınmaması, güzel ananelerin öne çıkarılıp hoş bulunmayan tarafların çok defa anlatılmaması, bilimsel değil edebi bir üslup kullanılması temel eleştiri noktalarıdır. Köy sosyolojisinde elde edilen verilerin değerlendirilmesi konusunda şöyle bir öneri getirilmiştir: "Halbuki cemiyet ${ }^{26}$ bir bütündür.

${ }^{24}$ Niyazi Berkes, "Modern Ekonominin Tezatlarından Faşizm”, Yurt ve Dünya, S. 33, Eylül 1943, s. 330

${ }^{25}$ Niyazi Berkes, "Emperyalizm”, Yurt ve Dünya, S. 40, 15 Şubat 1944, s.115 1941, s.26.

${ }^{26}$ Mediha Berkes, “Türk Köyünün Tetkikine Başlarken”, Yurt ve Dünya, S. 1, İlkkanun 
Her adet ve ananenin ancak o cemiyetin bütünü içinde bir manası ve fonksiyonu vardır."

Ankara köylerinde gelenekler ve gündelik hayat üzerine yapılan incelemeler, 1940'lı yıllarda Türk devriminin köylere ne kadar ulaşabildiği konusunda ilginç tespitler içermektedir: Pazar için üretim yapan ve şehirle yakın temas kuran köylerde modern tıptan yaralanılırken bu niteliği taşımayan köylerde kocakarı yöntemleri ile tedavi usulleri bütün yaygınlığıyla yaşamaktadır. Köylerde isimler genelde Arapçadır ve lakaplar soyadına göre daha yaygın olma halini sürdürmektedir. Soyadlar genelde öztürkçe olmakla birlikte evlenme, miras ${ }^{27}$ gibi resmi işlemler dışında çok az kullanılmaktadır. Çocuk ölüm oranlarının dikkat çekici yüksekliğine, bu ölümlerin köylü tarafından nasıl anlamlandırıldığına ve bu konudaki yaygın yanlış düşüncelere de yer verilmiştir. ${ }^{28}$ Ölen çocukların ana babaya ahirette şefaatedeceğine inanılırken, ölen çocuk için devletin ceza vereceği veya vergi alacağı gibi yaygın yanlış inançlardan dolayı ölüm vakalarının genelde bildirilmediği tespit edilmiştir. ${ }^{29}$ Zaten nüfusa kayıtları da yapılmamıştır. Ayrıca resim nikah da soyadı gibi yaygınlaşmamıştır.

Hukuksal zeminde Cumhuriyetle birlikte tanınan haklara rağmen köylerde kadınların, haklar, çalışma, değer verilme ve eşitlik konularındaki geleneksel konumunda bir değişme söz konusu değildir. Köyde yaşayan ve dergi yazarlarınca olumsuzluk olarak değerlendirilen alışkanlık ve gelenekler, bunları yaşatan şartlar çerçevesinde değerlendirilmiştir. Soyadı ve resmi nikâhın yaygınlaşmaması, köylüleri bu işlemleri yapmaktan alıkoyan bürokratik zorluklar ile açıklanırken, doğum oranının yüksekliği ve kadının konumundaki değişmeme hali köydeki iktisadi faaliyetlerin hala emek yoğun olmasına bağlanmıştır. İnsan ve hayvan kuvvetinin yerini makinenin alamamass ${ }^{30}$ kadının ve çocuğun emeğinden yararlanılmasını zorunlu kılmaktadır. Sosyal şartlar değişirse yani zaman ve enerjide tasarruf edilebilirse kadın kendini geliştirebilir ve konumunda olumlu yönde bir gelişme olabilir. İstenmeyen alışkanlık ve gelenekleri değiştirmenin, bu gelenekleri yaşatan koşulları ortadan kaldırmakla mümkün olacağı en sık tekrarlanan tespit olmuştur.

Dergide, köyde yaşayan gelenek ve alışkanlıkları ele alan yazıların yanında köylülerin toprakla ilişkisi, üretimin ilkelliği, tarımın makineleşmesi gereği, köy nüfusunun azaltılarak sanayi için emek fazlalığı yaratılması gibi konuları ele alan yazılara da yer verilmiştir.

\footnotetext{
${ }^{27}$ Mediha Berkes, “Adlar ve Lakaplar”, Yurt ve Dünya, S. 5, May1s 1941, s. 35,36

${ }^{28}$ Niyazi Berkes, "Köy Nüfusu", Yurt ve Dünya, S.4, Nisan 1941, s. 19, 21.

${ }^{29}$ Mediha Berkes, "Köyde Șehirli", Yurt ve Dünya, S. 4, Nisan 1941, s. 37,38

${ }^{30}$ Mediha Berkes, "Kadının Durumu", Yurt ve Dünya, S. 21, Sonteşrin (Kasım) 1942, s.
} 331 
1940'lı yıllarda yaklaşık 40 bin köyü barındıran Türkiye'deki köy gerçeğine ilişkin tespitler çarpıcıdır: Zirai üretimimiz geniş ölçüde kara saban, nadas ve yağmur duasına dayanmaktadır. Harcanan emek yoğunsa da Türk çiftçisi ileri teknik uygulayan çiftçiden 5 kat az verim sağlamaktadır. ${ }^{31}$ Köylülerin üretim teknikleri ve doğa ile olan mücadelesindeki gerilik de şöyle ifade edilmiştir: "Binaenaleyh istihsal, köylünün emri altına girmesi lazım gelirken köylü, istihsale kul olmaktadır."32

Türk köylüsünün toprağa egemen olamama, daha geniş anlamıyla tarımsal üretimin geriliğgi hakkında ayrıntılı açıklamalar yapılarak çok az arazinin sulanabildiği, tarımda iptidai tekniğin kullanıldı $\breve{1}$, suni gübrelemenin yaygınlaşmadığı şeklindeki tespitlere yer verilmiştir.

Tarımdaki geri kalmışlık sebebiyle elli milyonu besleyebilecek olan Türkiye'nin 18 milyonu aşmayan vatandaşlarına refah sağlayamadığ iaşe darlığından dolayı bazı şehirlerde açlıkla yüz yüze gelindiği belirtilmiştir.

Tarımda bir anlamda neler yapılması gerektiğine ilişkin önerileri de içeren yukarıdaki tahlil, köylü ve toprak ilişkisini kökünden değiştirmenin, yani, tarımda modernleşmenin sanayileşme ile olan sıkı bağını da ele almışır.

Türkiye sanayisinin kalıcı ve kalifiye iş̧̧i bulmakta zorlandığı, üretim kapasitesini arttırmak için mütehassis bir işçi sınıfı yetiştirmenin zorunlu olduğu, böyle bir işçi sınıfının da toprak sahibi olma umudunu kaybeden, toprakla ve köyle bağalarını koparmış insanlardan kurulabileceği vurgulanmıştır.

Topraksız köylülerin sanayi merkezlerine akışının, önüne geçilemeyecek sosyolojik bir süreç olduğu da hatırlatılarak topră̆a dönüş fikrini savunanlar olduğu, bunların da, sanayileşme davasının şaşkın baltalayıcıları olduğu belirtilmiştir.

Tarımda makineleşme ve köyden sanayiye emek aktarma fikrinin, toprak reformuna bakışı da şekillendirdiğ görülmektedir. Bu çerçevede, topraksız köylüye toprak dağıtılması fikrinin istihsal davasıyla zannedildiği kadar yakın bir ilişkisi olmadığ $1^{33}$ belirtilerek topraksız köylülerin işgücü, sermaye, çift hayvanı, tohum yokluğu yaşadığı belirtilerek bu insanların bu nitelikleri ile dağıtılan toprağı işleyemeyeceği, yine ağaya yarıcılıkla işlettireceğ $\mathrm{i}^{34}$ savunulmuştur. Ayrıca köylüye bol miktarda zirai aletin

${ }^{31}$ Muvaffak Şeref, "Kültür Münakaşaları Karşısında”, Yurt ve Dünya, S.31, Temmuz 1943, s. 232

${ }^{32}$ Sitk1 Yircalı, "Büyük Köye Doğru", Yurt ve Dünya, S. 2, Subat 1941, s. 7

${ }^{33}$ Niyazi Ağırnaslı, "Toprak Dağıtımı" Yurt ve Dünya, S.33, Eylül 1943, s. 345

${ }^{34}$ Niyazi Ağırnaslı, "Zirai İstihsal Davamız", Yurt ve Dünya, S.42, 15 Mart 1944, s.182 
dağıtılmasının, bütün ülkede kooperatifler ve köy birlikleri kurmanın ekonomik olarak imkansız olduğu da vurgulanmıştır.

Geniş topraklarda verimsiz ilkel tekniklerle tarım yapmaktansa dar alanda yüksek verimli tarım yapmanın daha doğru olacağı ve boş kalan insan emeğinin sanayiye akacağı belirtilmiş, tarımda üretim artışı için; devletin örnek uygulamalar gerçekleştirmesi, tarım ürünlerinde aracıların kaldırılması, su, gübre, tohum ıslahı konularında çalışmalar yapılması önerilmiştir.

Tarım alanlarının parçalanarak küçülmesi de ele alınarak bunun sebebinin, veraset değil tohum, hayvan ve ziraat aletleri temin edememek olduğu vurgulanarak bu bölünmenin yasalarla engellenmeye çalışılması durumunda verimli işletilmeyen alanların bu vasfının korunacağı, oysa sermaye sahibi köylülerin bu alanları almasıyla sermaye gelişmesi yaşanacağı bunun da üretimi arttıracağı savunulmuştur. ${ }^{35} \mathrm{Bu}$ da bir anlamda toprakların sınırlı ellerde toplanmasının, dolayısıyla kentlere emek akışının savunulması anlamına gelmektedir.

Dergide, köylülerin üretim tekniklerindeki geriliğin, gündelik hayatın birçok cephesinde gözlenebileceğine ilişkin tespitlere de yer verilmiştir: Köylerde temizliğe önem ${ }^{36}$ verilmemekte, mikrop fikri bulunmamakta, tuvalet yaygınlaşmamış haldedir. Beslenme alışkanlıklarının savaşın da etkisiyle buğday, bulgur pilavı ve tarhana ile sınırlı olması bu olumsuzluğu daha da ağırlaştırmaktadır.

Köylülüğe ilişkin geri kalmışlık tespitleri, beraberinde çeşitli önerileri de getirmiştir. Türkiye'nin dağınık köy yapısı ve bu yapının köylere hizmetlerin götürülmesini engellediği belirtilerek dağınık köylerin birleştirilmesi savunulmuştur: “... nüfusuna göre beş köyü on köyü bir araya toplayarak asgari üç bin beş bin nüfuslu köyler vücuda getirmeliyiz". ${ }^{37} \mathrm{Bu}$ uygulamanın hem köylere hizmet götürülmesini kolaylaştıracağı hem de köylerden açığa çıkan artık nüfusun sanayideki işçi açığını gidereceğ savunulmuştur.

Dergide, köye dair konuların esas itibarıyla sanayileşme ve kentleşme çerçevesinde ele alındığı söylenebilir. Köy, tarım teknikleri modernleştirilerek üretimi arttırılacak ve bu yoldan ortaya çıkacak artık nüfusu ile sanayileşmenin ihtiyacı olan insan kaynağını sağlayacak alan olarak görülmüş̧tür.

${ }_{36}^{35}$ Şanda, “Köylü İşletmeleri Küçülüyor mu?”, Yurt ve Dünya, S.33, Eylül 1943, s. 333

36 Mediha Berkes yazısında 1943 yılında köylerdeki tifüs salgınının yaygınlığını beslenme ve temizlik alışkanlıkları çerçevesinde ele almaktadır. Mediha Berkes, "Köyde Sağlık", Yurt ve Dünya, S. 32, Ağustos 1943, s. 280-285.

${ }^{37}$ Sitk1 Yircalı, "Büyük Köye Doğru", Yurt ve Dünya, S.2, Şubat 1941, s. 13, 
Dergideki köy yazılarının tamamı değerlendirildiğinde köylülü̆̆g ilişkin çelişkili bir yaklaşımın varlığı da görülmektedir. Halkçı bir yaklaşımla, köylülerin aracı, tefeci ve ağa egemenliğinden kurtarılması istenirken; sosyolojik gerçeklerin 1şı̆̆ında da köy nüfusunun genel nüfus içindeki payının düsşeceği öngörülerek, bu sürecin hızlandırılması önerilmiştir. Başka bir ifadeyle bir yandan köylülerin daha insanca bir yaşam sürmesi, diğer yandan sanayinin ihtiyacı olan işçi sınıfını yaratmak için köylülerin köyle bağlarını koparması, kaybedecek bir şeyinin kalmaması savunulmuştur. Ancak buradaki çelişkinin, belki yazarların fikirlerinden daha çok, tarım toplumundan sanayi toplumuna dönüşecek bir ülkenin mukadder çelişki ve sancıları olduğu da gözden kaçırılmamalıdır.

\section{Şehirleşmeye Dair Yazılar}

1940'lı yıllar, tarımda genel bir makineleşme gerçekleşmemesi sebebiyle köyden kente akışkanlığın 1950'lere nispetle daha düşük olduğu bir dönemdir. Planlı sanayileşme politikaları ile geleneksel üretim biçimleri dönüşüme uğramaya, sanayi merkezleri kurulmaya ve buna bağlı olarak işçi sınıfında en azından sayısal bir artış vücuda gelmeye başlasa da Türkiye hala köylü niteliği ağır basan bir ülkedir.

Dergide yayınlanan kent yazıları köy yazılarına oranla sayısal olarak pek azdır. Ancak sayısal düşüklük, kent ve kentleşme konusuna ülkenin geleceği açısından atfedilen önemi azaltmamakta tersine köy yazılarını daha bütünlüklü şekilde anlamaya yardımcı olmaktadır.

Şehirleşmeye dair yazılarda köy yazılarında olduğu gibi saha çalışmasından elde edilen verilerin, sosyoloji bilimi ve Avrupa kentleşme tarihine ilişkin tarihsel bilgi birikimi çerçevesinde değerlendirildiği göze çarpmaktadır.

Kent yazılarında öncelikle, kentleşmenin belirgin özelliklerine ve Avrupa'nın bu alanda geçirdiği aşamalara dikkat çekilmiş, şehirleşme konusunda toplumlar, şehirleşmiş cemiyet ve şehirleri olan cemiyet şeklinde sınıflamaya tabi tutulmuştur. ${ }^{38}$ Şehirleri olan cemiyet, nüfusu şehirlere yı̆̆glan cemiyet şeklinde tanımlanırken; şehirleşmiş cemiyet adeta ideal ve Türkiye'de de gerçekleşmesi istenen cemiyet tipi olarak tasvir edilmiştir. Bu tip cemiyette şehrin tekniği köye girmiştir, ziraat makineleşmiş ve rasyonelleşmiştir. Köy şehre tabidir ve şehrin hususiyetleri köye girmiştir.

Türkiye, şehirleşme açısından geçirdiği aşama yönüyle ele alınırken kapalı ve yetimlik ekonomiden ulusal ekonomiye geçen bir ülke olarak betimlenmiştir. Kapalı ekonomik birimleri hala olsa da izlenen devletçi

${ }^{38}$ Behice Sadık Boran, "Şehir ve Şehirleşme Davamız", Yurt ve Dünya, S.3, 1941 Mart, s. $28-32$ 
ekonomi politikaları ${ }^{39}$ ile Batı Anadolu, Karadeniz ve Akdeniz bölgelerinde pazar için üretimin arttığı ve Türkiye köy hayatından şehre doğru bünyevi bir değişikliğin yaşandığı, yani şehirleşme sürecinin devam ettiği belirtilmiştir. Yavaş da olsa başlayan şehirleşme ile şehrin köyü değiştirici etkisi hissedilmeye başlanmıştır. Bu etki, kentin teknik, kültür ve davranış kalıplarının köyde yer etmeye başlaması şeklindedir.

Yukarıda belirtildiği gibi köy sorununun şehirleşmeyle bir bütün olarak ele alınması köyün, şehirleşmeye, başka bir ifade ile sanayileşmeye hizmet edecek ve onu tamamlayacak şekilde ele alınmasına ve ona bu çerçevede bir rol biçilmesine sebep olmuştur. Bu yaklaşım 1940'larda yaygın olan köyü ve köylülüğ̈̈i idealize etme anlayışı ile de zıtlık arz etmektedir: "Köy davası köye dönmek, köyü kendi iktisadi ve sosyal şartları içinde bırakmak değil bilakis o şartları değiştirmektir." köyü, şehrin seviyesine getirmektir.

Kentleşme olgusu işlenirken sanayileşmede yaşanan bazı sorunlar da ele alınmıştır. Bu, dolaylı olarak köy yazılarında da dile getirilen, çeşitli iş kollarında hissedilen "sürekli işçı” azlığıdır. Köylüler şehre mevsimlik çalışma amaçlı gelmekte, tarla ya da bir çift öküz alacak parayı biriktirmeyi düşünmekte ve bu gerçekleştiğinde köyüne dönmektedir. Bu sorunu aşmak, endüstriyi emek fazlasıyla desteklemek için köy nüfusunun azaltılması önerilmiştir: Köylünün, tekrar köye dönme imkanları olmamalı, teknik yoluyla köy nüfusu düşürülmeli, köylü bir öküzden fazlasını düşünecek ve alacak düzeye getirilmelidir. Şehirde iyi kazanmalı, ihtiyaçları çeşitlenmelidir.

Köylünün iktisadi olarak geçireceği sıçramanın onun dünya görüşlerini de değiştireceği fikri savunulurken işçilerin düşük ücretle çalıştırılmasına da karşı çıkılmış, köy kökenli işçilerin şehirde karşılaşacağı uyum ve yalnızlık gibi sorunlar için de tedbirler alınması istenmiştir: "O sadece bir fabrikanın yevmiye defterinde filan numaralı, şu kadar ücretli «bir işçi» değildir; her şeyden evvel bir insandır ${ }^{41}$ ve bir insan olarak meşgul olunmalıdır."

Dergide kentleşmeye ilişkin genel tahlillerin yanında yapılan saha çalışmaları, elde edilen bulgular ve çeşitli önerilere de yer verilmiştir. Ankara'da yapılan saha çalışmasında, Ankara'nın kasabadan modern bir şehre dönüştüğü ancak bu büyümede, Batı ülkelerinin şehirlerinde olduğu

\footnotetext{
${ }^{39}$ Nejdet Erzen, “Endüstri ve Şehirleşme Davamız”, Yurt ve Dünya, S.5, Mayıs 1941, s.

${ }^{40}$ Behice Sadık Boran, "Şehir ve Şehirleşme Davamız”, Yurt ve Dünya, S.3, 1941 Mart,

${ }^{41}$ Behice Sadık Boran, "Sanayide Köylü-İşçi”, Yurt ve Dünya, S. 15-16, Mart-Nisan
} $6,10,11,12$ s. 33 1942, s. 84. 
gibi ticaret ve sanayide yaşanan gelişmelerin değil başkent yapılmasının en önemli etken olduğu belirtilmiştir ${ }^{42}$.

Ticaret, sanayi ve modern teknik ilerledikçe şehirleşmenin hız kazanacağı belirtilerek Batı'da bu süreçleri yaşayan şehirlerin büyük sorunlar ile karşılaştığ 1 , benzer sorunların Türkiye'de de yakın gelecekte yaşanacağı belirtilmiştir. Bu çerçevede sosyal inhitat mintıkası olgusuna değinilmiş, Ankara'da yapılan araştırmanın sonuçları yorumlanmıştır. Çocuk suçlarını araştırmak amacıyla yapılan saha çalışmasında ${ }^{43}$ Ulus semtinin, şehirleşmenin sosyal sorunlarını bağrında barındırdığı tespit edilerek, mantar evli muhit tabiri ile de bir anlamda günümüze kadar ağırlığı hissedilecek gecekondulaşma ve bunun sosyal sonuçlarına dikkat çekilmiştir. Ulus, köylerden, kasabalardan gelmiş ve iş arayan vasıfsız kitleleri ile şehre uyum sağlayamayan, geleneksel ahlak kuralları çökmüş, çocuk suçlarının örgütlü hale geldiğ $\mathrm{i}$, şehir kurallarını benimseyememiş bir semttir: Ulus, “... serbest cinsi hayatın, evlenmeden beraber yaşamanın ve diğer aile bozukluklarının geniş mikyasta mevcut olduğu..." içtimai inhitat alanıdır.

Türkiye'de henüz ağır seyreden şehirleşme olgusunun Batı'da (İngiltere, Almanya, Amerika Birleşik Devletleri) daha erken dönemde yaşandığına dikkat çekilerek ${ }^{44}$ Türkiye'de de benzer süreçlerin yaşanacağı, bu konuda Batılı ülkelerin tecrübelerinden yararlanılması gereğine değinilmiştir. $\mathrm{Bu}$ çerçevede Batılı ülkelerde kentleşmenin doğurduğu sorunları çözmek yolunda halka temiz ve ucuz mesken temin etmek, gençlik teşkilatları ve dini teşekküller kurmak gibi uygulamalar ile çare arandığ 1 belirtilmiştir. Bu birikimden hareketle Türkiye'de kentleşmenin doğuracağ 1 sosyal sorunları çözebilmek için devletin, şehirleşme için tedbirler alması, planlı şehirleşme için çalışılması, belediyelerin de, şehir plancılığını şehrin sosyal hayatını da içine alacak şekilde düşünmesi gerektiği vurgulanmıştır.

\section{Ĕ̆itime Dair Yazılar}

Eğitim yazılarının Yurt ve Dünya dergisinde diğer konularda yazılanlara oranla daha az yer tuttuğu görülmektedir. Dergide Türkiye'nin kalkınması konusunda sanayileşmeye merkezi bir önem atfedilmesi bu azlığın açıklayıcısı olsa gerektir. Tarımda verimliliği arttıracak makineleşme ile köy nüfusu azaltılmalı, artık nüfus hızla yürütülecek sanayileşmenin ihtiyacı olan iş̧̧i açığını gidermelidir. Başka bir ifade ile Yurt ve Dünya dergisinde kalkınma, öncelikle bir eğitim meselesi değil, sanayileşme,

\footnotetext{
${ }^{42}$ Behice Sadık Boran, "Modern Şehir Örneği”, Yurt ve Dünya, S. 6, Haziran 1941, s. $15,16,17$ $34-40$

${ }^{43}$ Behice Sadık Boran, "Mücrim Mahaller", Yurt ve Dünya, S. 7, Temmuz 1941, s. 6,7

${ }^{44}$ Nejdet Erzen, "Endüstri ve Şehirleşme Davamız", Yurt ve Dünya, S. 5, Mayıs 1941, s.
} 
tarımda teknolojinin işe koşulması ve üretim artışı meselesi olarak ele alınmıştır.

Eğitim konusuna genel olarak, okullardaki eğitim anlayışının niteliği ve bunun genel hayat ile uyumsuzluğu, gençliğin eğitilmesi, geleneksel eğitim anlayışı, eğitime daha çok ahlak eğitimi olarak bakan anlayışın eleştirisi ve Köy Enstitüleri çerçevesinde değinilmiştir.

Osmanlı döneminden devralınan ve dini terbiyenin kendi niteliğinden kaynaklanan ezberciliğin okullarda hala devam etmekte olduğu, sınavların bu ezberciliği sürekli kılan etkenlerden olduğu vurgulanmıştır ${ }^{45}$.

Okulda, gelişmesine katılmadığımız bilgilerin verildiği bu bilgilerin toplumsal hayatımıza henüz girmediği yani gerçek hayatta karşılığı olmadığı bu yönüyle de eğitim ile sosyal hayat arasında uyumsuzluk olduğu belirtilmiştir.

Milli Eğitim Bakanlığı'nın 1943 yılındaki çalışmasının dergiyi de etkilediği görülmektedir ${ }^{46}$. Türkiye'nin yakın dönemde bir devrim gerçekleştirdiği, bunun yarattığı sarsıntının eğitimde de gözlendiğine değinilerek gençliğin, değişen sosyal ve siyasal hayatın gerektirdiği nitelikler ile değişmeyen ahlak ve eski eğitim kaideleri arasında $s 1 k 1 s ̧ t 1 \breve{g ̆}_{1}{ }^{47}$, eski kıymetlerden yeni kıymetlere geçişin doğurduğu sıkıntıların gençlerde daha çok hissedildiğ $i^{48}$ belirtilerek bir anlamda geleneksel yapılar ve anlayışların yıkılmamasının Cumhuriyetin eğitim yoluyla vermeye çalıştığı zihniyet önünde engel olduğu belirtilmiştir.

Geleneksel eğitimin gençler üzerinde yarattığı problemlerin köylerde daha çok hissedildiği zira buralarda eski anlayışların daha canlı olduğu, bu yapıdan özellikle kızların etkilendiği vurgulanmış, köydeki eğitimin özellikle kızlara itaati öğrettiğ $i^{49}$ vurgulanmıştır. Ayrıca okulun erkekler için gerekli kızlar için gereksiz olduğu anlayışının yaygın olduğu belirtilmiştir.

Eğitimin sosyal değişiklikler ile bir bütünlük içinde ele alındığı yazıların yanında eğitimde yöntem ve yeniliklere de değinilmiştir. Okul öncesi eğitim ve ana- baba eğitiminin gerekliliği ${ }^{50}$ üzerinde durulmuş ancak bu yeni eğitim uygulamalarının yaygınlaştırılabilmesinin mümkün olmadığ savunulmuştur. Gençliğin eğitilmesi meselesinde konuyu daha çok ahlak

\footnotetext{
${ }_{45}^{45}$ Niyazi Berkes, "Ezbercilik”, Yurt ve Dünya, S. 12, 1. Kanun 1941, s. 340-343

${ }^{46} 15$ Şubat 1943'te II. Milli Eğitim Şura'sının toplanması üzerine derginin 26-27. sayısı Gençlik Sayısı olarak çıkmıştır.

${ }^{47}$ Niyazi Berkes, "Gençliğin Sosyal Durumu", Yurt ve Dünya, S.26-27, Şubat-Mart 1943 , s. $48-57$

${ }^{48}$ Muzaffer Şerif Başoğlu, "Gençliğin Yetiştirilmesi”, Yurt ve Dünya, S.26-27, ŞubatMart 1943, s. 72

${ }^{49}$ Mediha Berkes, “Köy Gençliği”, Yurt ve Dünya, S.26-27, Şubat-Mart 1943, s.74

${ }^{50}$ Nemci Sarığlu, "Okulda Ahlak Terbiyesi”, Yurt ve Dünya, S. 26-27, Şubat-Mart 1943, s. 64.
} 
çerçevesinde ele alma anlayıșının yaygın olduğu, hatta bu anlayışın Şura'da bile gözlendiği belirtilmiş, laik ahlakın verilebilmesinin önemine değinilerek gençlere Kısas-1 Enbiya okutularak ahlaki değerlerin verilmesi yolundaki öneriler sert bir dille eleştirilmiştir.

Eğitime ilişkin yazılarda Köy Enstitüleri'ne geniş yer ayrılmıştır. Normal okullarda gözlenen bilgi-gerçek hayat kopukluğu sorununun, verilen eğitimin bütünlüğünden dolayı Enstitüler için söz konusu olmadığı belirtilmiştir. Köy Enstitüleri bütün yazılarda ezberciliğin terk edildiği, verilen bilgi ile sosyal hayat arasındaki kopukluğun giderildiği eğitim kurumları olarak değerlendirilmiştir. Enstitüler dışındaki okullarda eğitimöğretim ikiliği bulunduğu, alınan bilginin davranışa dönüştürülemediği, üstelik buna okulun engel olduğu vurgulanırken Enstitülerde, bilginin karakterde yer edecek şekilde uygulanma imkanının olduğu ifade edilmiştir.

Köy Enstitülerine ilişkin değerlendirmeler, Enstitülere yapılan tetkik gezilerinde elde edilen bulgular ile birlikte verilmiş, gözlenen öğrenci davranışlarına geniş yer ayrılmıştır: "Göze çarpan bir hususiyetleri de lise orta mektep talebelerinde pek az rastlanan, serbestçe fikirlerini ortaya sürme, müdafaa ve münakaşa edebilmeye alışmıs olmalarıdır." ${ }^{\text {.51 }}$

Halk-aydın ikiliğini kaldıracak, halk sanatından ilham alarak halkı tanımaya yardımcı olacak kişilerin yetişeceği kurumlar olarak değerlendirilen ve değişik yöre kültürlerinin kaynaştığı eğitim ortamları olarak da görülen Enstitüler, sıklıkla eğitimde teori-pratik bütünlülüğünün sağlanabildiği okul tipi olarak değerlendirilmiştir: "Burada ne ziraat ve zenaat, ne de ilmi bilgi ${ }^{52}$ hayattan ayrı, parça parça bilgiler ve meharetler halinde talebeye verilmiyor."

Yurt ve Dünya dergisinde Köy Enstitüleri sadece bir eğitim kurumu olarak ve eğitim anlayışına getirdiği yenilikler açısından ele alınmıştır. 1960'lı yıllardan itibaren ise sol akımların çoğunluğu, Enstitüleri, Türkiye'nin neredeyse her sorununu çözme kapasitesine sahip ama yarım bıraktırılmış bir girişim olarak değerlendirmişlerdir.

1940'11 ve 1960'l1 yıllarda Enstitüler hakkında yazılanların karşılaştırılmasının, Türk düşünce dünyasındaki dönemsel değişiklikler ve aynı konuya siyasal olayların ve kişisel dramların etkisiyle giderek farklı anlamlar yükleme eğilimlerini anlama açısından aydınlatıcı olacağı düşünülebilir.

\footnotetext{
${ }^{51}$ Müeyyet Boratav, "Batı Anadolu'da Yirmi Gün”, Yurt ve Dünya, S. 33, Eylül 1943, s. 349.

${ }^{52}$ Mediha ve Niyazi Berkes, "Toprağın Çocukları”, Yurt ve Dünya, S. 14, Şubat 1942, s. 3. Bu yazı, Çifteler Köy Enstitüsü'ne yapılan gezinin izlenimlerini de içermektedir.
} 


\section{Irkçılık ve Faşizm Eleştirileri}

Yurt ve Dünya dergisinde faşizm ve irkçıllık konusuna geniş yer ayrıldığı görülmektedir. Daha çok sert bir üslupla kaleme alınan bu eleştirel yazılar yazarların dünya görüşlerini yansıtmanın yanında dönem içinde Türkiye'de dergiler düzeyinde ifadesini bulan ırkçılık taraftarlığı ile de ilgilidir. Zira 1940'lı yıllar faşizm, Turancılık ve ırkçılığın ülkede revaç bulduğu yıllardır. Bundan dolayı anılan dönemdeki ırkçı ve sol eğilimli dergileri kısaca tanıtmak yararlı olacaktır.

Bozkurt: İstanbul'da Reha Oğuz Türkkan yönetiminde Mayıs 1939'da ${ }^{53}$ yayın hayatına başladı. Derginin diğer yazarları Sami Karayel, Nurullah Barıman, Nihal Atsız ve kardeşi Necdet Sancar'dır. Aşırı Türkçü tavrı sebebiyle 9. sayısında kapatıldı, 1942'de yayınına haftalık olarak tekrar başladı. Dergi, Turancı bir görünüm arz etse de temel kaygısı Türkçülüktü. Türkleri birleştirici unsurun ırk olduğu görüşünü savundu.

Çınaraltı: İstanbul'da Orhan Seyfi Orhon yönetiminde Ağustos 1941'de yayın hayatına başladı. Derginin diğer yazarları Nihal Atsız, Ahmet Caferoğlu, Hüseyin H. Erkilet, Hüseyin Namık Orkun, Zeki Velidi Togan ve Peyami Safa'dır. İsmail Gasprinski'nin "dilde, fikirde, işte birlik" ilkesini benimsedi. Irkçı kuramı ${ }^{54}$ savundu.

Ergenekon: Reha Oğuz Türkkan tarafından 1938 sonlarında Ankara'da yayınlanmaya başladı. İlk pantürkist ${ }^{55}$ ve ırkçının pancermanistler ve Hitler değil Türkler ve Mete olduğu fikrini işledi. Üç sayı çıktıktan sonra kapandı.

Gökbörü: Nihal Atsız'dan ayrılan Reha Oğuz Türkkan yönetiminde Kasım 1942'de yayın hayatına başladı. Türk Ocakları'nın ${ }^{56}$ ve Türk Yurdu dergisinin kapatılmasıyla Türkçülüğün iniş çağına girdiği, Türkçülük ülküsünü diriltmeye ant içen Bozkurtçuların şimdi ortaya çıktığı görüşünü işledi. Reha Oğuz Türkkan, Nihal Atsız ile kimin daha safkan Türk olduğu konusunda sert tartışmalara girişti. Mayıs 1943'te kapatıldı.

Büyük Doğu: İstanbul'da Eylül 1943'te yayın hayatına başladı. 1945 'ten sonra Necip Fazıl Kısakürek'in etkisiyle sol karşıtı İslamcı bir çizgiye kayd.

${ }^{53}$ Zafer Toprak, "Fikir Dergiciliğinin Yüz Yılı”, Türkiye'de Dergiler Ansiklopediler (1849-1984), Gelişim Yayınları, İstanbul, 1984, s. 47

${ }^{54}$ Zafer Toprak, "Fikir Dergiciliğinin Yüz Yıll”, Türkiye'de Dergiler Ansiklopediler (1849-1984), Gelişim Yayınları, İstanbul, 1984, s.47

${ }^{55}$ Zafer Toprak, "Fikir Dergiciliğinin Yüz Yılı", Türkiye’de Dergiler Ansiklopediler (1849-1984), Gelişim Yayınları, İstanbul, 1984, s.46,47. Günay Göksu Özdoğan, "Dünyada ve Türkiye'de Turanc1lık", Modern Türkiye'de Siyasi Düşünce, Milliyetçilik, C. 4, İletişim Yayınları, İstanbul, 2002, s. 400, 179

${ }^{56}$ Şerafettin Turan, Türk Devrim Tarihi, IV-1, Bilgi Yayınevi, Ankara, 1999, s. 178, 
Kopuz: Samsun'da Nisan 1939'da Fethi Tevetoğlu yönetiminde yayın hayatına başladı. 1940-1943 yılları arasında yayınlanmadı. Uygarlıktan uzak yaşayan Türk köylüsünün bu durumundan aydınları sorumlu tuttu. Türk kültürünü ve Türk ruhunu saklayan köylülüğü yüceltti, aydınlara köylü ile arasındaki derin uçurumu kaldırma görevi yükledi. Turancılık ${ }^{57}$ nedeniyle kapatıld1.

Adımlar: Ankara'da Mayıs 1943'te Behice Boran ${ }^{58}$ yönetiminde yayın hayatına başladı. Faşizm eleştirisine yer verdi. Güncel olayların toplumsal boyutlarını vurguladı. Yabancı ve yerli toplumcu gerçekçi yazarları tanıttı. Yazar kadrosu hemen hemen Yurt ve Dünya dergisininkiyle aynıdır.12 sayı çıktı. Mayıs 1944'te Yurt ve Dünya dergisi ile birlikte kapatıldı.

Ant: Hakkı Bigeç ${ }^{59}$ yönetiminde Mart 1945 'te yayın hayatına başladı. Diğer yazarları Adnan Cemgil, Nusret Hızır, İlhan Başgöz, Arif Damar, Muvaffak Şeref, Enver Gökçe, Behice Boran, İlhan Berk, Rüştü Şardağ idi. Sosyalist sanat görüşünü savundu. 1940 kuşağının Faşizm’e ve Nazizm’e karşı çıkan şairlerinin coşkulu şiirleriyle dikkati çekti.

Yürüyüş: Fazıl Mahmut ${ }^{60}$ Ülkücü yönetiminde Temmuz 1941'de yayın hayatına başladı. Diğer yazarları Sait Faik, Orhan Kemal, Kemal Sülker, Burhan Arpad, Ömer Faruk Toprak, Rıfat Ilgaz, Samim Kocagöz, Kemal Bilbaşar'dır. II. Dünya Savaşı yıllarında Türkiye'de yaşanan ağır baskılar karşısında özgürlük isteklerini sanatla buluşturma kavgasına girdi. Dönemin koşullarından dolayı sosyalizm fikrini örtük bir biçimde savundu.

Ses (1939), Sokak ( 1940), Küllük (1940), Yeni İnsanlık (1940), Yeni Edebiyat (1940), Gün (1946), Yığın (1946), Dost (1946), Hür Gençlik (1946), Söz (1946) de yine bu dönemin diğer sol eğilimli dergileri olarak anılabilir.

Yurt ve Dünya dergisinde ırkçılığa ilişkin ilk yazı 1941 yılında yayınlandı. Toplumlar arasındaki kültürel farklılıkların izahının ${ }^{61}$ ırk farklılıklarıyla yapılmasının yanlışlığına değinilirken; kültür farklarının biyolojik özellikler değil diğer kavimlerle temas, şahsi deha ve coğrafi mevki dikkate alınarak yapılmasının gereği vurgulanmıştır.

\footnotetext{
${ }^{57}$ M. Orhan Bayrak, Türkiye'de Gazeteler ve Dergiler Sözlüğü (1831-1993), Küll Yayınları, İstanbul, 1994, s.79

${ }_{58}$ Erdal Doğan, Edebiyatımızda Dergiler, Bağlam Yayınları, İstanbul, 1997, s. 207

59 Vedat Günyol, "Cumhuriyet Sonras1 Sanat ve Edebiyat Dergileri", Türkiye'de Dergiler Ansiklopediler (1849-1984), Gelişim Yayınları, İstanbul, 1984, s. 100 37

${ }^{60}$ Erdal Doğan, Edebiyatımızda Dergiler, Bağlam Yayınları, İstanbul, 1997, s. 35, 36, 1941, s.42
} 
Irkçıllı̆̆ın bilimsel araştırma sonuçlarına yer verilerek eleştirilmesi de dergideki yaklaşımlardandır. Bu amaçla Amerika Birleşik Devletleri ve Avrupa ülkelerinde yapılan ırklar arası mukayeseli zeka ölçümlerinin sonuçlarına yer verilmiştir. Buna göre; ABD'de zenciler ile beyazlar arasında zeka farkı yoktur. Sadece muhit, insanca ${ }^{62}$ muamele görüp görememe, gelişmeye müsait şartlar bulma durumları zekaca az bir fark yaratmıştır. Aynı bilimsel bulguların Avrupa ırkları için de geçerli olduğu vurgulanmış Nordik, Alpen ve Akdeniz gruplar arasında ciddi zeka farkları olmadığı, var olan farkların yukarıda değinildiği gibi sosyal şartlardan kaynaklandığı belirtilmiş̧ir.

Irkçılığın, ırklar arasındaki araştırma sonuçlarına dayanılarak eleştirilmesinin yanında, Avrupa'nın ekonomik ve teknik açıdan daha geri olan uluslar ile olan tarihsel ilişkileri ve kapitalizmin tahlili çerçevesinde de ele alındığı görülmektedir. Irk üstünlüğü iddialarının ortaya çıkışının toplumların sınıflı hale gelmesiyle gündeme geldiği vurgulanmıştır: “...üstünlük iddialarına biz ancak insan ${ }^{63}$ cemiyetinin sınıflara bölündüğü tarihten itibaren rastliyoruz". Eski Yunan ve Roma'dan Almanya ve İtalya'ya uzanan tarihsel süreçte değişik kavramlarla ifade edilen üstünlük iddialarının hakim sınıfların yabancı milletleri istila veya kendi konumlarını sürdürmek için bir topluluğu düşman göstererek dikkati başka yöne yönlendirme çabasının ürünü olduğu belirtilmiştir.

Irkçılı̆̆ın Türk tarihi açısından ele alındı $\breve{g} 1$ yazılarda ise tarihsel olarak ırkçılığın Türk toplumunda dayanağı olmadığı vurgulanmış, 1940'lar Türkiye'sinde 1 rkçılığın taraftar kazandığı belirtilerek, dönemin 1 rkçı dergilerinde yazılanlara tepki anlamında, Ziya Gökalp'ten alıntılar ile Gökalp'in ${ }^{64}$ ırkçı olmadı̆̆ı belirtilmiştir. Avrupa ırkçılığının, istila, halkı kandırma planlarının meşrulaştırıcısı olduğu belirtilerek Türkiye'deki ırkçıların Türk halkı arasında ayrılık yaratacak mahiyette olduğuna dikkat çekilmiştir.

Türkiye'de ırkçılığa taraftar olanların belirgin özelliklerinin neler olduğuna ilişkin yazıların da kaleme alındığı görülmektedir. Buna göre; modern teknik aleyhtarl $\breve{g ̆}_{1}{ }^{65}$, gelenekçilik ve üretimde geleneksel yöntemleri savunmak Türk ırkçılarının baskın özellikleridir. Bu kesimler milli ilim ve kültür başka, medeniyet başkadır ayrımından hareket etmekte olup sanatı da sosyal meseleler ile alakası olamayan bir alan olarak görmektedirler.

${ }^{62}$ Muzaffer Şerif Başoğlu, "Psikoloji Karşısında Irkçıllk", Yurt ve Dünya, S. 25, Sonkanun 1943, s.6-12

${ }^{63}$ İhsan Berksoy, "Irk Üstünlüğ̈̈ İddiaları”, Yurt ve Dünya, S. 41, 1 Mart 1944, s. 154

${ }^{64}$ Niyazi Berkes, "Irk ve Irkçllk", Yurt ve Dünya, S.24, 30 İlkkanun 1942, s. 438,439 Berkes, yazısında Türkiye'deki ırkçılık taraftarları için oldukça sert ifadeler kullanmıştır: “....rkçı fikirleri bizde derhal benimseyen manyaklar..." s. 439.

${ }^{65}$ Muvaffak Şeref, "Fikir Hayatımızda Geri Temayüller", Yurt ve Dünya, S. 36, İlkkanun 1943, s. 470,471, 472 
Irkçı1lı̆̆ın koyu milliyetçilik olarak tanıtıldığına da değinilmiş yürüyen, yükselen Türk cemiyeti ile koyu milliyetçilerin bir bağının olamayacağı savunulmuştur. Irkçılık Batı dünyasının çürümüş hali olarak değerlendirilirken bu fikrin Türkiye'deki savunucularının Batı'daki örnek aldıklarıyla birlikte geri sosyal yapıları savundukları ifade edilmiştir: "Bizi çıkrık, kağnı ve karasaban medeniyetinde ${ }^{66}$ yerinde sayar görmek isteyen emperyalistlere bilerek bilmeyerek hizmet eden ilerilik düşmanlarının gerçek milliyetçilikle en ufak ilgileri olamaz".

Yurt ve Dünya dergisindeki ırkçılık karşıtı yazılarda 1940'larda Türkiye'de ırkçı temelde yayın yapan bazı dergiler de ele alınmıştır. Gökbörü dergisi "Her sayfasından boğucu bir kan kokusu tüten bu derginin ${ }^{67} . . . "$ şeklinde sunulmuş; yine aynı dergiden alıntılar yapılarak Atsızlar, Çınaraltıcılar, Bozkurtçular, Gökbörücülerin belli menfaatler karşılığı idealist ve Türkçü göründükleri iddia edilerek, bu menfaat ne acaba denilerek Türkçülerin Almanya ile parasal ilişkileri olduğu ima edilmiştir. Türkçülerde görülen, sorunları Yahudi düşmanlığı merkezinde açıklama ve örneğin, intihar ve benzer sosyal sorunlardan Yahudileri sorumlu tutma yaklaşımı eleştirilerek; köy ağası da Yahudi mi? diye sorulmuştur.

Dergide genel olarak CHP ve milli şef İsmet İnönü için saygılı ifadeler kullanılmışsa da belki de en net CHP eleştirisi yine ırkçılık taraftarları ile CHP'nin bazı önde gelenleri arasındaki ilişkiler ele alındığında görülmüştür. $\mathrm{Bu}$ çerçevede Ziraat vekili Şevket Raşit Hatipoğlu ile Çanakkale mebusu Reşat Nuri Güntekin'in Gökbörü'de ${ }^{68}$ yazı yazması şüphe ile karşılanarak Laik ve İnkılapçı olan Milliyetçilik umdesinin ırkçılık ile bağdaşmayacağı belirtilmiş bir anlamda adı geçen kişiler Altı İlke açısından eleştirilmiştir.

İkinci Dünya Savaşı'nın sonlarına doğru dergide demokrasi çerçevesinde faşizmin yenilgisini işleyen yazılar görülmeye başlamıştır. Yüzyıl başlarında dünyanın, sayıları yüzü aşmayan sermaye krallarının oyuncağı haline geldiği, kapitalizmin, Birinci Dünya Savaşı sonrası karşılaştığı bunalımı aşmak için faşizme yöneldiği belirtilmiş ancak bu sürecin de sonuna gelindiği savunulmuştur: "Faşizmin sonu yaklaşırken demokrasi fikri, tarihin kaydetmediği bir ölçüde geniş halk kütlelerini sarmış bulunuyor." ${ }^{69}$

\footnotetext{
${ }^{66}$ Adnan Cemgil, "Koyu Milliyetçilik Nedir?", Yurt ve Dünya, S.41, 1 Mart 1944, s.165. 394.

${ }^{67}$ Adnan Cemgil, Olduğu Gibi-Içyüzleri, Yurt ve Dünya, S. 22-23, İlkkanun 1942, s. 397

68 Adnan Cemgil, Olduğu Gibi-İçyüzleri, Yurt ve Dünya, S. 22-23, İlkkanun 1942, s.

${ }^{69}$ Y. D, “Günün Terimleri-Demokrasi”, Yurt ve Dünya, S. 37, Sonkanun 1944, s. 5. Dergideki bazı yazılarda imza olarak Yurt ve Dünya derginin baş harflerinin kısaltması olan YD kullanılmıştır. Yazılardaki üslup, Adnan Cemgil tarafından yazıldı ğını düşündürmektedir.
} 
Irkçılığa yönelik sert eleştirilerin yanında eğitim ile propagandanın karşılıklı olarak ele alındığı da göze çarpmaktadır. Buna göre eğitim akıl ve mantığa seslenirken ${ }^{70}$ propaganda hislere seslenir. Heyecanlara seslenmesi, tenkit ve muhakemeye yer vermemesi yönüyle tehlikeli bir usuldür. Bu tehlikeli usulün giderek eğitime de egemen olduğu ve irkçılığa hizmet ettiği savunulmuştur.

\section{Bilim ve Tarih Yazılart}

Yurt ve Dünya dergisinde bilim ve bilimin Türkiye'deki düzeyi hakkında yazılar da kaleme alınmıştır. Bu yazıların değerlendirilmesi derginin Türkiye'de bilime yüklediği görevi anlama açısından önem taşımaktadır. Hemen belirtmek gerekir ki Türkiye'de bilimin durumuna dair yazılanlar genellikle olumsuzlukla yüklüdür.

Türkiye'nin sosyal alanda birçok değişiklikler ve bunlardan doğan problemler yaşamasına rağmen sosyal bilimlerin bu problemleri ele alıp çözmekten uzak olduğu belirtilmiştir. Sosyal bilimlere ilişkin bu olumsuz tespit genel olarak bilimin durumuna da teşmil edilerek Batı ile karşılaştırmaya gidilmiştir: “...biz hala ilmi müstakil bir hale getiremedik. Yani geçmişte olduğu kadar bile bir ilim ananesi, terbiyesi, zihniyeti kuramadik.,"ᄁ1

Türkiye'de bağımsız bir bilim yaratma ihtiyacının şiddetle hissedilmesine rağmen, Türklere özgü ilim olmalıdır şeklinde bilimin evrenselliğini göz ardı eden anlayışın, bunun gerçekleşmesi önünde büyük engel olduğu savunulmuştur. Bilim alanında gelişmeleri takip etmek, dünya tefekkür hadiselerini bilmek, kanunlarını anlamak, bilimi insanların ihtiyaçlarına göre kullanmak, olayların gidişine karışabilmenin, tecrübelerden yaralanabilmenin, usullerini kullanabilmenin ve nihayetinde ona büyük şeyler katabilmenin yapılmayı bekleyen ödevler olduğu vurgulanmıştır.

Batılı ülkelerde Almanya'da, Amerika Birleşik Devletleri'nde, Rusya'da bilimin halka mal edildiği ve sosyal hayatta inkılapçı bir unsur haline getirildiği belirtilerek Türkiyede bu aşamaların henüz gerçekleşmediği belirtilmiştir.

Bilimin Türkiye'de gelişebilmesi için yukarıda değinilen eksikliklerin giderilmesi yanında; bilimi kendi sorunlarımıza uyarladığımızda bilimin bizim olacağı, ilmin yerleşebilmesi için bakışların maddi, manevi tabiata

\footnotetext{
${ }^{70}$ Behice Sadık Boran, "Propaganda ve Terbiye", Yurt ve Dünya, S. 12, 1. Kanun 1941, s. 364

${ }^{71}$ Niyazi Berkes, "İlim Dünyasındaki Durumumuz”, Yurt ve Dünya, S. 20, 29 İlkteşrin 1942 , s. 271
} 
çevrilmesi, yılmadan sorunların rasyonel kafa ile çözülmeye çalışılması gereği vurgulanmıştır.

İlme aykırı düşünüş tarzlarına aydınlar arasında da rastlandığına ${ }^{72}$ dikkat çekilerek bu anlayışa örnek olarak açıklanamayan sorunların Allahın hikmeti veya ırk gibi olgularla açıklandığı belirtilmiştir. Bunun yanında ilim konusunda Türkiye'nin, örgütlenmeye, bilimler arası işbirliğine, iyi yetişmiş araştırmacılara ve uzmanlaşmaya ihtiyaç duyduğu belirtilmiştir. Günün şartları ve olaylarının etkisiyle bilimin politikanın hizmetine girdiği bunun da bilimsel zihniyetin gelişimi önünde önemli bir engel olduğu savunulmuştur.

Sosyolojinin bir bilim dalı olarak sunduğu imkanlar da dergide ele alınan konulardandır. Tarih içinde uygarlığın sağladığı gelişmeler sonucu insanın doğa ile olan ilişkilerinde tıpta, üretimde bilimin egemen olmasına karşılık insanın insanla olan ilişkilerini hala gelenek, inanç, heyecan ve ilcaların $^{73}$ tanzim ettiği tespiti yapılarak bu halin toplumsal çatışmaları hazırladığı belirtilmiştir. Sosyolojinin bu alanı ve bu alanda yaşanan sorunları rasyonel esaslar üzerinde geliştirme gücüne sahip olduğu belirtilerek sosyal bilimlerin gelişmesi ve bazı alanlarda uygulamaya geçmesi buna kanıt olarak gösterilmiştir.

Bilime dair yazılarda Charles Darwin'e özel bir önem atfedildiği görülmektedir. Darwin'in hayatı ve eserleri tanıtılırken onun, evrim teorisini insana uyguladığı ve ikna edici delillerle insanın eski maymun bir atadan doğduğunu kanıtladığı savunulmuştur. Bu tespitin, insanın yaratılışına ilişkin geleneksel yaygın inancı da yerle bir ettiği şöyle belirtilmiştir: " Darwin ${ }^{74}$ insanın ve hayvanların çamurdan bugünkü şekillerinde yaratılmayıp tekamül yolu ile meydana geldiklerini göstermek sureti ile bir kainat terakkisini değiştirmiş ve batıl itikatları yıkarak ilmin ilerlemesi için yolu açmıştır."

Darwinizm karşısında Avrupa'daki çeşitli düşünce akımlarının, sınıfların ve kilisenin tavrı da dergide geniş olarak ele alınmıştır. Buna göre Darwinizm Avrupa'da kilise ve burjuvazinin egemen konumlarına ağır bir darbe vurmuştur ve Darwinizm'in gördüğü tepkileri, egemen sınıflar ve

${ }^{72}$ Faşizmin, bilimi politikanın hizmetinde kullanma çabası eleştirilirken Ülkü dergisinde, B. Bedri Tahir Şaman'ın bu anlayışı Türkiye'ye getirmeye çalışan yazılar yazdığı belirtilmiştir. Niyazi Berkes, "İlim Dünyasındaki Durumumuz", Yurt ve Dünya, S. 20, 29 Illkteşrin 1942, s. 275. 154

${ }^{73}$ Behice Sadık Boran, "İptidailik ve Medenilik”, Yurt ve Dünya, S. 9, Eylül 1941, s.

${ }^{74}$ Muzaffer Şenyürek, "Charles Darwin: Hayat1 ve Eserleri", Yurt ve Dünya, S. 39, 1 Şubat 1944, s. 89. Şenyürek, insanın zaman içindeki tekamülünü ele aldığ 1 bir başka yazısında, evrim teorisinin, insanın maymundan geldiğini, bunun bir nazariye değil bir hakikat olduğunu bu hakikati de her münevverin kabul etmesi gerektiğini savunmuştur. Muzaffer Şenyürek, "İnsanın Tekamülü̈, Yurt ve Dünya, S. 6, Haziran 1941, s. 36 
çıkarları çerçevesinde ele almak gerekir: "Darwinizm" ${ }^{75}$ tarafından kuvvetli bir darbe yiyen Hıristiyanlık akidelerini sosyal menfaatleri bakımından kullanan bütün gerilik taraftarları tekamülcü görüşün inkılapçı vasfını sezmişlerdi."

Dönemin bilim adamlarına bile korkunç gelen evrim teorisinin, insanlığın gelişiminde Hıristiyanlık, devlet, mülkiyet ve sınıfların olmadığı bir hayatı kanıtladığı belirtilerek Darwinizm'e yönelen tepkinin ekonomik olgulara dayandığ 1 vurgulanmıştır. Darwinizm'in fikirlerine özellikle burjuva ideologlarınca cephe alındığına, ancak cephe almanın yanında evrim teorisinin kapitalizmin yararına kullanıldı ̆̆ına da dikkat çekilmiştir: "Çok geçmeden burjuva ideologları ${ }^{76}$ Darwinizm'in bazı fikirlerini alarak kapitalizmin, fertçiliğin... emperyalizmin nihayet... ırkçılığın meşru ve zaruri olduğunu, bunların tabiatın kanunlarına dayanan gerçekler ve zaruretler olduğunu ispat için kullandılar.” Bu çerçevede Spencer, Bagehot, Gumplowicz, Ratzenhofer, Lapouge, Ammon, Galton ve Pearson Darwinizm'i emperyalizm ve ırkçılık yolunda kullanan düşünürler olarak zikredilmiştir.

Darwin'in düşünüş tarihindeki ileri ve olumlu etkileri olarak da: “...insanın ${ }^{77}$ tanrı tarafından yaratıldığı imanını altüst etti;...hıristiyanlığın insanın cennetten kovulduğu ve günahkarlığı efsanesini yıktı; mucize, peygamberlik, duaya karşı beslenen itikat yerine, aklın, ... kuvvetini gösterdi: ruh, Allah gibi din inanışlarının... ilmi olarak tetkik edilmesine yol açtı." değerlendirilmesine yer verilmiştir. Bunun yanında Darwinizm'in diğer bilim dallarına katkısı olarak; psikolojinin, Darwin'den sonra ilmi bir mahiyet alabildiği de belirtilmiştir.

Darwin'in tabii seçiliş nazariyesinin burjuva ideologlarınca sosyal hayata uygulanma çabası da; "Sosyal alemde ${ }^{78}$ mevcut olan mücadele biyolojik faktörle izah edilemez; çünkü burada uzvi alemde mevcut olmayan faktörlerin rolü vardır" şeklinde eleştirilmiştir.

Darwinizm'e dair yazılarda göze çarpan bir husus vardır ki; o da dergide her konuda çok net hissedilen kuşkucu ve eleştirel yaklaşımın Darwinizm için söz konusu olmamasıdır. Başka bir ifade ile Darwin'in görüşleri neredeyse mutlak doğru olarak kabul edilmiştir.

Dergide sınırlı sayıda da olsa tarih yazılarına rastlanmaktadır. Bu yazılar daha çok Türk düşünce tarihi üzerinedir. Bir taraftan Osmanlı

${ }^{75}$ Niyazi Berkes, "Darwinizm Karşısında İleri ve Geri Düşünüşler", Yurt ve Dünya, S. 39, 1 Şubat 1944, s. 92

${ }^{76}$ Niyazi Berkes, "Darwinizm Karşısında İleri ve Geri Düşünüşler", Yurt ve Dünya, S. 39, 1 Şubat 1944 , s. 93

7 Niyazi Berkes, "Darwinizm Karşısında İleri ve Geri Düşünüşler”, Yurt ve Dünya, S. 39, 1 Subat 1944, s.94

${ }^{38}$ Niyazi Berkes, "Darwinizm Karşısında İleri ve Geri Düşünüşler”, Yurt ve Dünya, S. 39, 1 Şubat 1944 , s.95 
modernleşme süreci, özellikle düşünce akımları çerçevesinde ele alınırken diğer yandan aynı dönemi ele alan yazılar ve bu yazılarda saptanan yaklaşımlar eleştirilmiştir. Buna göre Osmanlı 1slahatları, batılılaşması ve Batıdan gelen düşünce akımlarını ele alan mükemmel bir eser henüz yazılmamış olmasına rağmen bu konuda kesin olarak yerleşmiş bazı kanaatlerden söz edilmektedir. Bu yaygın ama yanlış kanaate göre ${ }^{79}$ Osmanlı mütefekkir ve edipleri sadece Fransız kültür ve edebiyatının etkisinde kalmışlar bu hal Tanzimat döneminde de sürmüş ve sonuçta Fransız ölçülerini benimsemekle garplılaştığımız zehabı doğmuştur.

Fransız düşünce ve edebiyatının ağırlıklı olarak etkili olduğu tespiti doğru olmakla birlikte bu etkide Avrupa'ya giden Osmanlı kişilerinin keyfi tercih veya kaprislerinin ve tesadüflerin belirleyici olduğu fikrinin yanlış olduğu, Namık Kemal ve Ziya Paşa'nın uzun süre İngiltere'de yaşamalarına rağmen Fransız kültürünün etkisinde kaldıklarına ancak bununla birlikte dönemin Fransız sosyalizmi, Comte felsefesi ile ilgilenmediklerine işaret edilmiştir.

Fransız etkisini anlamanın anahtarı olarak tarihi şartların dikkate alınması gerektiği vurgulanarak Fransa'nın, yakın şarkla diğer emperyalist ülkelere nazaran daha önce alakalı olduğu, 1789 devrimi ile Avrupa fikir hayatında ayrıcalıklı bir mevkide bulunduğu, tesirin yalnızca Osmanlı ile sınırlı olmayıp aynı etkinin Rusya ve küçük Avrupa ülkeleri için de söz konusu olduğu belirtilmiştir. Fransız tefekküründeki "liberalizm ve terakki felsefesi”nin Osmanlı burjuvazisinin iştiyaklarına hitap ederken Alman ve İngiliz tefekkürünün bu cazibeye sahip olmadığı belirtilmiştir.

Osmanlıda etkili olan fikir akımlarında bu akımların geldiği ülke kadar Osmanlının yaşadığı sorunlar, hakim cereyanlar, temayüller, arayışlar ve aranışların da dikkate alınması gerektiği vurgulanarak iç yapı ve sorunların etkilenmedeki belirleyiciliğinin önemi belirtilmiştir. Şikayet edilen Fransız tesiri konusunda iç koşulların belirleyiciliği şu cümlede verilmiştir: "Dışarıdan gelen malların nevinde olduğu gibi, fikir piyasamıza ${ }^{80}$ şu veya bu "kültür"ün girişinde iç sosyal şartların geniş ölçüde tesiri olmuştur."

Osmanlı tarihine ilişkin başka bir yazıda da laiklik ele alınmış ve Osmanlı tarihi ve Cumhuriyet sürecine ilişkin tahliller yapılmıştır. Kelimenin etimolojik anlamına dair yapılan açıklamalardan sonra İslam tarihinde Peygamber, Dört Halife ve Emeviler döneminde İslam devletinin teokratik nitelikte olduğu tespitine yer verilmiştir.

${ }^{79}$ Niyazi Berkes, “Garpten Gelen Düşünceler”, Yurt ve Dünya, S. 34, I. Teşrin 1943, s. 276

${ }^{80}$ Niyazi Berkes, "Garpten Gelen Düşünceler", Yurt ve Dünya, S. 34, I. Teşrin 1943, s. 
Osmanlı batılılaşma çabaları ile laikleşme anlamında ortaya çıkan farklılaşmaya da şöyle dikkat çekilmiştir: “...Tanzimat'ın ${ }^{81}$ yaptı ğı şey, devletin vazifeleri arasına dini mülahazalar ve müesseseler dişında kalan yeni vazifeler ve müesseseler getirmiş olmasıdır." Bu olgunun Cumhuriyete dek sürecek her alanda görülen bir ikilik yarattığı; Tanzimat ve Meşrutiyet fikir ve devlet adamlarının doğu değerleriyle batı değerlerini uzlaştırmaya çalışırlarken dinin mutlak irade elinde bir vasıta olduğunu göremedikleri belirtilmiştir.

Olaylar, toplumsal gelişmeler ve değişmelerin telifçi yaklaşımı yalanladığı, maddi alandaki değişimlerin manevi medeniyetin kaideleriyle devamlı bir çatışma yarattı̆̆ 1 belirtilerek bu birikim ve açmazların laikleşmeyi zorunlu bir adım haline getirdiği şu cümle ile açıklanmıştır: “...hulasa garp medeniyeti denen medeniyeti alabilmek için devlet, siyaset, hukuk, ekonomi, maarif, aile, muaşeret, kıyafet alanlarında artık din ölçülerinden kurtulmuş bir zihniyetle harekete geçmek lazımdı." 82

$\mathrm{Bu}$ zorunlu aşamanın da, Cumhuriyet dönemindeki Saltanat ve Halifeliğin kaldırılması ve Medeni Kanun'un kabulü gibi adımlarla gerçekleştirildiği şöyle belirtilmiştir: “ Bütün bu inkılapçı adımlarla, cumhuriyet devrinde sosyal hayat dinlerden ve dinlerin koyduğu naslardan değil, hayatın kendinden ${ }^{83}$ ve onun icaplarından mülhem olarak istikamet almak imkanlarını kazanmış oldu."

Dergide yer verilen başka bir yazıda da Namık Kemal ve Osmanlı Devleti'ne ilişkin fikirleri ele alınmıştır. Namık Kemal'in makalelerinden yola çıkılarak yapılan tahlilde; Kemal'in, Osmanlı İmparatorluğu'nun inkırazının başlıca sebebi olarak devlet teşkilatındaki kusurları gördüğü belirtilmiştir. Onun, Locke, Hobbes ve Rousseau gibi düşünürlerden etkilendiği vurgulanarak hürriyet, müsavat hakkındaki fikirleri ve teklif ettiğgi meşruti hükümet şekli yönleriyle XIX. Yüzyıl Liberalizminin temsilcisi ve savunucusu olduğu yorumuna yer verilmiştir. ${ }^{84}$ Böyle olmakla birlikte Kemal'in, devletin kamu hizmeti görmesi gereğine karşı çıkan düşünceleri ile öz Liberalizmden ayrıldığı vurgulanmıştır. Bunun yanında eğitimin zorunlu olmasını kabul etmesi itibarıyla Namık Kemal'in, yine tam liberalizmden ayrıldığı, "devletçilik"e öncülük ettiği belirtilmiştir.

\footnotetext{
${ }^{81}$ Niyazi Berkes, "Türk İnkılabında Laikliğin Gelişmesi”, Yurt ve Dünya, S. 35, Sontessrin 1943, s. 430

${ }_{82}$ Niyazi Berkes, “Türk İnkılabında Laikliğin Gelişmesi”, Yurt ve Dünya, S. 35, Sonteşrin 1943, s. 434

${ }_{33}$ Niyazi Berkes, "Türk İnkılabında Laikliğin Gelişmesi”, Yurt ve Dünya, S. 35, Sontessrin 1943, s. 434, 435

${ }^{84}$ Behice Sadık Boran, "Namık Kemal'de Devlet Fikri”, Yurt ve Dünya, S. 1, Sonkanun 1941, s. $17-25$
} 
Dergide yayınlanan iktisat yazılarında görülen bütün olumlu sıçramaların gerçekleşmesinde Cumhuriyet dönemini milat olarak kabul etme anlayışı, Osmanlı düşünce tarihine dair yazılarda, tarihsel sürekliliğgi daha çok dikkate alan bir anlayışa dönüşmüştür. Başka bir ifade ile tarih yazılarında Cumhuriyete ulaşan süreçte katkısı olan Osmanlı düşünsel birikimi, örtük bir biçimde de olsa, daha çok önemsenmiştir.

\section{Yurt ve Dünya'nın Dönemin Düşünce Dünyasına Bakışı}

1940'lı yıllar, gündelik hayat açısından birçok sıkıntıların ve yoklukların yaşandığı dönem olmasına karşın aynı yıllarda Hasan Ali Yücel'in Milli Eğitim Bakanlığ döneminde doğu ve batı klasiklerinden Tercüme Bürosu'nca gerçekleştirilen çeviriler, İnönü Ansiklopedisi'nin yayınlanması ve Türkiye genelinde yayınlanan dergilerdeki artış, dönemin düşünsel zenginliğine işaret etmektedir.

Yurt ve Dünya, bu dönemin canlı bir dergisi olarak, isim vererek veya vermeden dönemin ırkçı-turancı dergilerine keskin eleştiriler yöneltirken zaman zaman diğer dergi, kişi ya da anlayışları da tahlil etmiştir. 1944 yılında derginin 37.sayısındaki uzun değerlendirme ${ }^{85}$ bize Yurt ve Dünya dergisinin Türkiye'de yayınlanan dergilere ve Milli Eğitim Bakanlığı öncülüğündeki çalışmalara nasıl baktığını göstermektedir.

Türkiye'deki geri (reaksiyoner)- ileri (inkılapçı) çatışması gibi dünyada da ileri-geri (faşizm-hürriyetçi ileri güçler) çatışmasının mevcudiyeti belirtilirken Türkiye'de ileriye yönelen fikir hareketleri olarak İnönü ${ }^{86}$ ansiklopedinin yayını, Tercüme Bürosu'nun çevirileri ve Yurt ve Dünya dergisi zikredilmiştir. Burada dergi kendisini, “...müsbet ilim görüşü fikirde ve sanatta gerçekçilik, sosyal görüşte halkçılık ve inkılapçılıktır." şeklinde tanımlamıştır.

Ülkü, içinde bazı iyi yazılara rastlansa da genel olarak; şahsiyetini bulamamış, tekniği parmak hesabı, ideolojisi yavan köy romantizmi olan ve otokritik ve kritik yapılmadan, sipariş üzerine yayın yapan bir dergi olarak değerlendirilmiştir.

Adımlar dergisinden olumlu sözlerle bahsedilirken İnsan dergisi istikrarsız olarak nitelenmekte, Halkevleri'nin, yayınladığı dergiler kastedilerek, imkanları paralelinde yayın yapamadığı savunulmuştur.

İsmail Hakkı Baltacıŏ̆lu, Türk'e Doğru isimli kitabından dolayı olumsuz bir fikir odağı olarak ele alınmış, Mustafa Şekip Tunç da Türkiye'de Bergsonculuğu canlandıran kişi olarak eleştirilmiştir: "Tekniği geri ilim alanında geri, ilim alanında birkaç asırlık bir gecikme halinde

\footnotetext{
$8-18$

${ }^{85}$ Adnan Cemgil, "Geçen Y1lın Fikir Hayatı", Yurt ve Dünya, S. 37, Sonkanun 1944, s.

86 “İnönü Ansiklopedisi iște, irticaın hakim olur gibi göründü̆̆ü devrimizde, dünyanın bir tarafı karanlıklara gömülürrken başka bir yanın nura koştuğunu müjdeliyor." Adnan Cemgil, "Ansiklopedi”, Yurt ve Dünya, S. 3, 1941, s. 37
} 
bulunan ve henüz eski rejimin yıkıntıları üzerinde yeni hayatı kurmaya çalışan Türkiye'ye lazım olan müspet ilmin değerini küçümseyen, aklı inkar eden bir mistisizm ${ }^{87}$ değil, müspet ilim ihtirası, makine sevgisi, müspet ve realist bir dünya görüşü idi."

Ziyaettin Fahri Fındıkoğlu, Suut Kemal Yetkin, Yunus Nadi Abalığlu ve Mustafa Hakkı Akansel hakkında olumsuz değerlendirmeler yapılırken Çı̆̆ır dergisi, Peyami Safa'nın savaşı yücelten, faşizm taraftarı yazılarına kucak açmakla suçlanmıştır. Sadi Irmak da, "faşizmin yenilgisinin belirginleşmesi üzerine cezbeli taraftarı olduğu Nitzsche'ciliğin cenaze marşını söylemeye başladı" şeklinde değerlendirilmiştir. Yine Cermen ırkçılığının gözde fikri olan "antisemitizm"i büyük bir coşkunlukla müdafaa etmiş olan B. Tahsin Banguoğlu'nun, ırk üstünlüğü fikrinin "aşağılık duygusunun" mahsulü olduğunu söyleme noktasına geldiği belirtilmiştir. Samet Ağaoğlu ise Millet dergisinde "faşizmin ölmediğine kendisini ve başkalarını inandırmaya çalışıyor" şeklindeki ifadelerle eleştirilmiştir.

Dergilerin yanında romancılara dönük eleştirilere de yer verilen yazılarda Halide Edip Adıvar'ın inkılapçı değil, ıslahatçı ${ }^{88}$ ve muhafazakar olduğu, Yakup Kadri Karaosmanoğlu'nun da köy toplumuna nüfuz edemediği savunulmuştur.

Dönemin romancılarından olan Muazzez Tahsin Berkand; Sonsuz Gece, Bahar Çiçeği, O ve Kızı, Kerime Nadir; Hıçkırık, Kabahat Bende mi, Mebrure Sami de Leylaklar Açarken adlı romanları çerçevesinde değerlendirilmiş ve adı geçen eserler; “ ...hepsi vıcık vıcık, yapışkan fazla şekerli bir şurup gibi iç bayıltıcı bir santimantalizm ${ }^{89}$ ile doludur." şeklinde değerlendirilmiş, bu eserlerde geçen şahısların adeta içtimai bir boşlukta yaşadıkları belirtilmiştir. Liseli gençlerin bu eserleri okumalarının onları edebi bir terbiye edinmekten alıkoyacağı da vurgulanmıştır.

1940'ların düşünce hayatına ilişkin yapılan genellemelerde, Türkiye'de düşünsel derinliği olmayan sı ̆̆ aydınlara dair sert eleştirirler de göze çarpmaktadır: "Bizde birkaç sahifeden fazla yazı okumaya tahammülü olmayan bir "yarı münevver" 90 zümresi vardır: bunlar... ruhları hasta, iradeleri gevşek...bir takım psikopatlardır."

$\mathrm{Bu}$ olumsuz değerlendirmelerin yanında Sabahattin Ali, Sait Faik Abasıyanık, Bekir Sitkı Kunt, Kemal Bilbaşar, Cemalettin Mahir, Orhan Kemal realizmin hikayecilikteki gelişimine örnek olarak gösterilmiş, Ruhi Su da sazı milli ifade kabiliyetini bozmadan modernleştiren kişi olarak takdim edilmiştir.

13

${ }^{87}$ Adnan Cemgil, "Geçen Yılın Fikir Hayatı”, Yurt ve Dünya, S. 37, Sonkanun 1944, s.

${ }^{88}$ Behice Sadık Boran, "Halide Edib'in Yeni Romanları”, Yurt ve Dünya, S. 5, 1941, s.

${ }^{89}$ Behice Sadık Boran, "Kadın Romancılarımız”, Yurt ve Dünya, S. 8, 1941, s.74

${ }^{90}$ Sabahattin Ali, "Yarı Münevver", Yurt ve Dünya, S. 30, Haziran 1943, s. 212. 
Yurt ve Dünya dergisi yazarlarının eleştirilerini anlamak açısından, değerlendirmelerinde ölçütlerinin ne olduğu, aydın kavramına nasıl baktığı, ona ne gibi sorumluluklar yüklediğine bakmak aydınlatıcı olacaktır: “...sanatkarın"1 mesuliyeti su götürmez. Sahip olduğu intihap ve tayin hürriyetini, sanatının ve geniş halk kütlelerinin selameti için dosdoğru kullanması icap eder... Oturduğu evde ve mahallede... mahkemede ve cephedeki insanı görmeyen sanatkar yarımdır, hatta yarım bile değil hiçtir! Yaşadığı devrin İnsan problemlerini ve insana ait her türlü endişeyi, davayı en geniş manasıyla eserlerine mevzu seçen sanatkar, vazifesini hakkıyla yaptığına, ancak böyle bir neticenin sonunda anlaşılacağına emin olabilir."

Türkiye gibi ilerleme yolunda olan bir toplumda aydının, halka bakışı, geri bir toplumu ilerilere götürmedeki görev ve sorumluluğu şu cümleler açıklanmaktadır: "İleri"92 aydın halk adamıdır. Ve, en ziyade müşahhas davalarını, dertlerini anlayabileceği kendi milletine faydalı olmak şartlarına, imkanlarına, kudretine sahip olduğunu bilir....Kısaca, ileri aydın, geriliğinden acı duyduğu cemiyetinin ilerlemesi şartlarını bir kimya formülü açıklığıyla bilecek, bu şartların gerçekleşmesine çalışacaktır."

\section{Tanitım Yazılart}

Yurt ve Dünya dergisinde yer alan tercümeler ve tanıtım yazılarına bakıldığında ilk sayıda duyurulan yurt ve dünyayı birlikte anlama çabasının hayata geçtiği söylenebilir. Bu çerçevede Ludwig Van Beethoven, Bach, Charles Dickens, Rus tenkitçi Belinsky, film sanatçısı Paul Muni, Şarlo, rejisör Max Reinhardt, Fransız edebiyatçı Romain Rolland, Macar romancısı Geza Gardonyi ve Erksıne Caldwel'in kısa yaşam öykülerine yer verilmiş ve eserleri tanıtılmıştır.

Yukarıda ele alınan yazılar dışında folklor, edebiyat, halk hikayeciliği, dil meseleleri, enerji ve sulama gibi birçok farklı konuda yazılar yazılmış ayrıca Çin Aile sisteminin bozuluşundan Afrika kıtasında yaşanan siyasal, dini, sosyal değişimlere, Hindistan'ın bağımsızlık mücadelelerinden bulaşıcı hastalıklarla mücadeleye kadar dünyanın farklı ülkelerinin konularına dair bol miktarda çeviriye yer verilmiştir.

\section{Derginin Kapatılmast}

II. Dünya Savaşı yılları, Türkiye'de basın özgürlüklerinin kısıtlandığı, gazete ve dergi kapatmalarının yoğun olarak yaşandığ Haziran 1938'de kabul edilen Basın Kanunu, hükümetlere basın üzerinde sıkı bir denetim kurma imkanı vermekteydi.

${ }^{91}$ Suat Taşer, "Anlaşılmayan Sanatkar”, Yurt ve Dünya, S. 39, 1 Şubat 1944, s. 96,97

${ }^{92}$ Muvaffak Şeref, "Geri Cemiyetin İleri Aydını", Yurt ve Dünya, S. 37, Sonkanun 1944, s. 24,25 
“...Matbuat Kanunu'nun 50. maddesi gereğince, "memleketin umumi 93 siyasetine dokunacak neşriyattan dolayı, İcra Vekilleri Heyeti kararı ile, gazete veya mecmualar, muvakkaten tatil olunabilir(di)...Bu suretle kapatılan bir gazetenin mesulleri, tatil müddetince, başka bir isimle gazete çıkaramazdı." Anılan dönemde basının, daha çok İstanbul basınından ibaret olması ve 1940 yılından itibaren İstanbul'daki sürekli sıkıyönetim uygulaması, basın üzerindeki baskıyı arttırıcı bir diğer etkendi.

Hükümetlerin, gazete ve dergilere karşı olan tutumunu, izlenen dış politikanın ve hükümete karşı oluşacak toplumsal tepkiyi önlemek düşüncesinin belirlediği söylenebilir.

Türkiye, II. Dünya Savaşı başladığında savaşın dışında kalmak için bir denge politikası izlemeye başlamıştı. Bu dış politikanın paralelinde hükümetler, Basın Kanunu'na dayanarak, gazetelerde Almanya, İngiltere ya da Sovyet yanlısı yazılar arasında bir denge sağlamaya çalışmış, başka bir ifade ile basını, izlenen dış politikayı destekleyecek şekilde biçimlendirmek istemişlerdir.

Savaş yıllarında alınan askeri tedbirler sonucu tarımsal üretim düşmüş, gıda maddelerinde darlık ve büyük fiyat artışları yaşanmıştı. Toplumun geniş kesimlerinin gündelik hayatını zorlaştıran bu gelişmelere stokçuluk, karaborsa, devlet görevlilerinin de katıldığ 1 yolsuzlukların eklenmesi ve bu olaylara özellikle gazetelerde yer verilmesi hükümetlerin basına karşı sert tutumunun bir diğer sebebiydi.

Gazetelerin sınırlamalara uymaması hükümetlerin sert tepkisine neden olmuş "Nitekim o yıllarda Vatan" gazetesi 9 kez, Tasvir 8, Tan 7 ve Cumhuriyet 5 kez kapatılmıştı."

Hükümetlerin yayınlanan dergilere karşı tutumunu yukarıda değinilen olgulardan daha çok dergiler arasında yaşanan sert polemiklerin ve II. Dünya Savaşı ile ilgili gelişmelerin belirlediği söylenebilir.

Türkiye, savaş yıllarında tarafsız bir politika izlemekle birlikte Almanya ile yoğun ticari ve siyasi ilişkiler kurmuştu. Sovyetler Birliği'nin dağılmasına yol açacak bir Alman zaferi ile Ortaasya Türklüğü ve Turan sorununun önem kazanma olasılığını dikkate alan İnönü ve CHP iktidarı, resmi düzeyde olmamakla birlikte Almanya'nın bu konudaki görüşünü

${ }^{93}$ Cemil Koçak, Türkiye'de Milli Şef Dönemi (1938-1945), 2. C, İletişim Yayınları, İstanbul, 1996, s. 135. "Bakanlar Kurulu gerekli gördüğü anda dilediği gazeteyi, dilediği sürece kapatacaktır. Bu kararlar kesindir, ne Meclis karışır bunlara, ne de Danıştay”. Hıfzı Topuz, 100 Soruda Türk Basın Tarihi, Gerçek Yayınevi, İstanbul, 1973, s. 162

${ }^{94}$ Şerafettin Turan, Türk Devrim Tarihi, IV-1, Bilgi Yayınevi, Ankara, 1999, s. 177. “...Bir gazete kapanırsa, ki gazeteler sık sık birkaç günlüğüne kapatılmaktadır, örneğin bir bakanın suistimalinden bahsettiği için kapanmaktadır." Yakup Kadri Karaosmanoğlu, Politikada 45 Yll, Bilgi Yayınevi, Ankara, 1968, s. 169 
öğrenmeyi ve yurt içindeki Turanist çevrelere belirli bir oranda hareket serbestliği tanımayı gerekli görmüştü. Böylece ulusalcı ya da ırkçı ve Turancı yayınlara izin verilmişti. Solcu/sosyalist yayınlar da gözetim altında tutulmaya çalışıldığından, bu davranış o yıllarda güdülen dengeci siyasaya da ters düşmemişti. Önemli olan, savaşın gidişine göre taraflar, ${ }^{95}$ sağ ve sol arasında esneklik gösterebilmekti.

Dergilerin kapatılmasında, dış politika gelişmeleri yanında, ırkçı-turancı dergilerle sol-sosyalist dergilerin birbirlerini giderek artan bir şekilde suçlamalarının da etkili olduğu anlaşılmaktadır. Zira 1942 sonlarında dergilerin gerilimi arttırıcı yayınlarına karşı alınacak önlemleri belirlemek amacıyla Milli Eğitim Bakanı Hasan Ali Yücel'in başkanlığında bir komisyon oluşturmuştu. Komisyon'un, Ocak 1943'te Başbakan Şükrü Saraçoğlu'na sunduğu raporda, bazı dergiler "herhangi bir fikri objektif ve bitaraf olarak değil, yüksek sesle telkin eder mahiyette ve şiddetli polemik yapar" şeklinde nitelenmişti. Bunlar arasında Yürüyüş, komünist; Yurt ve Dünya, ${ }^{96}$ sol eğilimli; Gökbörü ise rrkçılık yapan sağ eğilimli dergiler olarak sınıflandırılmıştı.

2 Şubat 1943 tarihinde Almanların Stalingrad önlerinde ${ }^{97}$ kesin bir yenilgiye uğraması Türkiye'nin dış politikasında büyük bir değişiklik yaratmıştı. 1944 Mayıs'ında Almanya'ya krom satışı durdurularak ABD ve İngiltere'ye yaklaşmanın zeminini oluşturmak için ırkçı- Turancılara dönük kovuşturmalara, cezalandırmalara ve dergilerinin kapatılmasına başlanmıştı.

“...iç politikada da izlenen denge politikası sonucunda, Turancı yayın organlarının kapatılmasından hemen önce ve sonra, hükümet ${ }^{98}$ kararı ile ve Matbuat Kanunu'nun 50. maddesi uyarınca, sol eğilimli olan Adımlar ile Yurt ve Dünya dergisi, 16 Mayıs 1944 tarihinde süresiz olarak kapatılır."

Yurt ve Dünya dergisinin resmen kapatılması Mayıs ayında gerçekleşse de aslında dergi daha önce yayınını durdurmuştur: "Milli Eğitim Bakanı Hasan Ali Yücel, Şubat 1944'te Yurt ve Dünya adına Boratav ve Berkes'i... makamına çă̆ırır. Irkçı-Turancıların gemi iyice azıya aldıklarını ve

${ }^{95}$ Şerafettin Turan, Türk Devrim Tarihi, IV-1, s. 177, 178

96 Şerafettin Turan, İsmet İnönü Yaşamı, Dönemi ve Kişiliği, Kültür Bakanlığı Yayınları, Ankara, 2000, s. 252

${ }^{97}$ Baskın Oran, "İç ve Dış Politika İlişkisi Açısından İkinci Dünya Savaşında Türkiye'de Siyasal Hayat ve Sağ -Sol Akımlar", A. Ü. SBF Dergisi, 23 (3), 1969, s. 253

98 Sol eğilimli dergilerden Yürüyüş, Temmuz 1943; Barış Dünyası, Haziran 1944; İslamcı dergi Büyük Doğu, Mayıs 1944; rrkçı-turancı dergilerden Çınaraltı, Mayıs 1944; Gökbörü, Mayıs 1943; Orhun, Nisan 1944; Kopuz, Mayıs 1944 tarihlerinde hükümet tarafından kapatılmışlardır. Cemil Koçak, Türkiye’de Milli Şef Dönemi (1938-1945), 2. C, İletişim Yayınları, İstanbul, 1996, s. 210, 227, 359. "Ankarada 11 Kanunusani 1941 tarihinde tesis edilen on beş günlük "Yurt ve Dünya" mecmuası İcra Vekilleri Heyetinin 16 Mayıs 1944 tarihli kararıyla ve Matbuat Kanununun 50. maddesine tevfikan kapatılmıştır. Ayın Tarihi, Haziran 1944, s. 452 
parlamentodan da çok fazla baskı geldiğini söyleyip aslında kapatılmaları için hiçbir nedenin olmadığını belirterek yayına bir süre ara ${ }^{99}$ vermelerini rica eder.” Bunun üzerine, Mart 1944'teki 42. sayısından sonra derginin yayını durdurulmuştur.

Hasan Ali Yücel'in ifade ettiği Meclis baskısı, Yurt ve Dünya dergisinin ve diğer sol dergilerin kapatılmasında, ırkçı-Turancı dergilerin kapatılmasını dengeleme amacından öte olguların varlığını göstermektedir.

Yurt ve Dünya dergisine karşı olan tepki ve düşmanlıkların sebebi olarak; derginin gerçekçi bir köy imajı vermeye çalışması gösterilmektedir: "Köylünün zaruret içinde olduğunu söylemenin komünistlik sayıldığı ve köyün pastoral ${ }^{100}$ bir romantizm içinde düşünüldüğü o günkü toplumda bütün bunların epey ileri bir sol düşünce sayılması gerekir.” Buna, 1940'1 yıllarda Türkiye'de, sosyolojinin sosyalizm olarak algılanması ve sosyalizmi savundukları iddia edilenlerin Sovyetler Birliği ile işbirliği halinde, kökü dışarıda oluşumlar olarak algılanması da eklenebilir. Ayrıca Yurt ve Dünya dergisi, bunu amaçlamamış da olsa, saha çalışmalarına dayanan somut bilgilerle, hükümetlerin, köylülüğe dönük başarısızlıklarını da gözler önüne sermişti.

Hükümetlerin teşviki, ırkçı-Turancı dergilerin yayınları ile Ortaasya'nın yeniden fethedilme hülyalarının canlandırıldığı, toplumun ağır iktisadi bunalımlarla karşı karşıya kaldığı bir dönemde; Yurt ve Dünya dergisinde, Darvinizm konularında, alışılmış geleneksel ve dinsel değer yargılarını sarsacak yazıların yayınlanmış olması, dergi ve yazarlarına karşı oluşan tepkinin bir diğer sebebi olsa gerektir.

1940’lı yılların olay ve olgularından olan Köy Enstitüleri karşıtlığı, Tan Olayı, Sabahattin Ali-Nihal Atsız davası,1948 DTCF Tasfiyesi, Hasan Ali Yücel-Kenan Öner Davası ve sol partileri içermeyen bir demokrasinin kurgulanması; Türkiye'nin, Mustafa Kemal ile başlayan tarihsel doğrultusundan sapma anlamına gelen zincirleme bir değişim yaşadığına işaret etmektedir. Batıdan dışlanma korkusu, savaş yıllarının memnuniyetsiz kitleleri ve iktidarı ele geçirecek kadar güçlenen burjuvazi olgularının şekillendirdiği siyasal gelişmeler içinde Yurt ve Dünya dergisinin kapatılması, zincirin halkalarından sadece biridir.

Derginin kapatılmasını, DTCF Tasfiyesi'nin izlemesi, Berkes, Boratav ve Boran'ın yaşayacakları dram ve sıkıntıları hazırlamanın yanında, sosyoloji biliminin gelişiminde ve büyük bir sosyal değişim yaşayan

\footnotetext{
${ }^{99}$ Meltem Ağduk Gevrek, “Yurt ve Dünya/1941-1944 1940'ların “solunun” Ankara Çevresi”, Toplum ve Bilim, S. 78, Güz, 1998, s. 268, 269

${ }^{100}$ Baskın Oran, "İç ve Dış Politika İlişķisi Açısından İkinci Dünya Savaşında Türkiye'de Siyasal Hayat ve Sağ -Sol Akımlar", A.Ü. SBF Dergisi, 23 (3), 1969, s. 263
} 
Türkiye'ye sunacağı imkanlar konusunda da bir kırılma ve kopma da yaratmıştır.

\section{Dĕgerlendirme}

Fikirlerin, kişilerin ürünü olduğu gibi kişilerin de, dönemlerinin ürünü oldukları, modern tarihçilikte genel kabul gören bir yaklaşımdır. Bu yaklaşım, Yurt ve Dünya dergisine uyarlandı̆̆ında; derginin yazarlarının, yaşları itibarıyla, Cumhuriyet'le birlikte büyüdüğü, Atatürk'ün, Türk devrimini Batının bilimsel birikimi ile takviye etme anlayışı doğrultusunda eğitim amacıyla çeşitli Batı ülkelerine gönderildiği görülmektedir.

İlk sayısında Türkiye'nin sorunlarının dünyadaki gelişmeler ve problemler ile birlikte ele alınacağını duyuran Yurt ve Dünya dergisi, zengin bir içeriğe sahip olmakla birlikte, ırkçılık-Turancılık ve faşizm eleştirisi ile Türkiye'nin sosyolojik şartlarını tespit ederek önerilerde bulunmaya özel bir önem vermiş, bu konulara sayfalarında daha geniş yer ayırmıştır.

II. Dünya Savaşı'nın başlamasında birinci derecede rol oynayan ve Türkiye'de hatırı sayılır oranda taraftar bulan ırkçılık ve faşizm, dergi yazarlarınca, Kemalizm'in ilkeleri ile bağdaşmayan, dolaylı da olsa geri kalmışlığın ürettiği değerleri yüceltmesi yönüyle kalkınma çabalarını köstekleyici, iç barışı zedeleyici bir ideoloji olarak değerlendirilmiş ve çok sert bir dille eleştirilmiştir.

Sosyolojik gözlemlerle desteklenen tahlillerde 1940'ların Türkiye'si; köylülüğü ağır basan, geleneksel üretim biçimlerinin dönüşüme uğramadığı, şehirleşmenin henüz başlangıç aşamasında olduğu, batıl inanç ve uygulamaları yaşatan, Kemalizm'in kültür ve hukuk alanında getirdiği yeniliklerin yerleşmesini engelleyen geri sosyal yapıların henüz kırılamadığı bir ülke olarak tasvir edilmiştir.

Dergide, Türkiye'nin kalkınma ve ilerlemesine daha çok Batı'da yaşanan süreçlerin 1 şı̆̆ında yaklaşılmış, sanayileşme ve şehirleşmeye merkezi bir önem atfedilerek çeşitli öneriler sunulmuştur. Bu çerçevede, köylerde hızlı bir makineleşmenin, şehirlerde planlı bir sanayileşmenin temel politika olması gerektiği vurgulanmıştır. Böylece tarımda üretim artışı sağlanırken açığa çıkacak artık köy nüfusunun sanayinin ihtiyacı olan kalıcı işçi ihtiyacını gidereceği belirtilmiştir.

Yurt ve Dünya dergisinde, kapitalizmin tarihsel gelişimine dair eleştirilere yer verilmesi ve Türkiye'nin sosyal-ekonomik sorunlarının, sınıfsal tahlillerle ele alınması, derginin Marksist olarak nitelenmesinde etkili olmuştur. $\mathrm{Bu}$ nitelemenin kısmen doğru olduğu belirtilmelidir. Zira dergide beliren Marksizm, daha çok “yöntem”le sınırlı olan bir Marksizm'dir. En basit ifade ile alt yapının, üst yapıyı belirlediğinden hareketle; gelenekler, batıl inançlar, Kemalizm'in yerleşmeyen kazanımları, 
bunları yaşatan veya kökleşmesini engelleyen geri sosyal ve ekonomik yapıların varlığı ile açıklanmıştır.

Kapitalizmin Avrupa'daki gelişimine ilişkin sert eleştiriler Türkiye söz konusu olduğunda haksız kazanç elde eden türedi zenginlerin kınanması şekline dönüssmüştür. Sınırlı kesimler için söz konusu olan ölçüsüz sermaye birikimi, daha çok toplumun yaşam koşullarını zorlaştırdığı için eleştirilmiş ancak tüccar ya da henüz yeşeren burjuvazinin tasfiyesi ima bile edilmemiştir. Bu yönüyle Yurt ve Dünya yazarları I. Dünya Savaşı yıllarının Solidaristlerini çağrıştırmaktadır.

Dergi yazarlarının, dönemin baskıları sebebiyle Sosyalizmi tam olarak savunamayacakları, dikkate alınmış olan bir olgu olmakla birlikte; makalelerde yer verilen analizlerde Türkiye, sosyalizme hazır bir ülke olarak değil, feodal yapıları yıkarak Cumhuriyet'in kurumlarını ve değerlerini kalıcı kılması gereken bir ülke olarak betimlenmiştir. Başka bir ifade ile Kemalizm'in üst yap1 değişikliklerinin, alt yap1 dönüşümleri ile tamamlanması gereği savunulmuştur.

\section{KAYNAKÇA}

Ayın Tarihi, Haziran 1944

Bayrak, M. Orhan, Türkiye'de Gazeteler ve Dergiler Sözlü̆̈̈̈ (1831-1993), Küll Yayınları, İstanbul, 1994. Doğan, Erdal, Edebiyatımızda Dergiler, Bağlam Yayınları, İstanbul, 1997.

Gevrek, Meltem Ağduk, "Yurt ve Dünya/1941-1944 1940’ların “solunun” Ankara Çevresi", Toplum ve Bilim, S. 78, Güz, 1998.

Günyol, Vedat, "Cumhuriyet Sonrası Sanat ve Edebiyat Dergileri", Türkiye'de Dergiler Ansiklopediler (1849-1984), Gelişim Yayınları, İstanbul, 1984.

Hilav, Selahattin, "Düşünce Tarihi (1908-1980)", Türkiye Tarihi 4 Çağdaş Türkiye 1908-1980, Cem Yayınevi, İstanbul, 1992.

Karadeniz, Abdurrahim, Düşünce ve Edebiyatımızda Yurt ve Dünya Dergisi, Kültür Bakanlığı Yayınları, Ankara, 2002.

Karaosmanoğlu, Yakup Kadri, Politikada 45 Yll, Bilgi Yayınevi, Ankara, 1968.

Koçak, Cemil, Türkiye'de Milli Şef Dönemi (1938-1945), C. 2, İletişim Yayınları, İstanbul, 1996.

Küçük, Yalçın, "Cumhuriyet Döneminde Aydınlar ve Dergileri”, Cumhuriyet Dönemi Türkiye Ansiklopedisi, C.I, İletişim Yayınları, İstanbul, 1983. 
Oran, Baskın, "İç ve Dış Politika İlişkisi Açısından İkinci Dünya Savaşında Türkiye'de Siyasal Hayat ve Sağ -Sol Akımlar”, A.Ü. SBF Dergisi, 23 (3), 1969.

Özdoğan, Günay Göksu, "Dünyada ve Türkiye'de Turanc1lık”, Modern Türkiye'de Siyasi Düşünce, Milliyetçilik, C. 4, İletişim Yayınları, İstanbul, 2002.

Toprak, Zafer, “Fikir Dergiciliğinin Yüz Yılı”, Türkiye'de Dergiler Ansiklopediler (1849-1984), Gelişim Yayınları, İstanbul, 1984.

Topuz, Hıfzı, 100 Soruda Türk Basın Tarihi, Gerçek Yayınevi, İstanbul, 1973.

Turan, Şerafettin, İsmet İnönü Yaşamı, Dönemi ve Kişiliği, Kültür Bakanlığ Yayınları, Ankara, 2000.

Turan, Şerafettin, Türk Devrim Tarihi, IV-1, Bilgi Yayınevi, Ankara, 1999.

Ülken, Hilmi Ziya, Türkiye’de Çağdaş Düşünce Tarihi, 3. Baskı, Ülken Yayınları, İstanbul, 1992.

Yurt ve Dünya Dergisi, 42 Sayı, (1941-1944). 